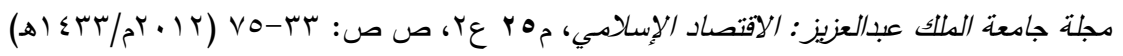
DOI: 10.4197 / Islec. 25-2.2

\title{
العلة الاقتصادية لتحربم ربا النسيئة والفضل
}

\author{
عبدالرحيم عبدالحمي الساعاتي \\ أستاذ - معرج الاقتصاد الإسلامي عيدي \\ جامعة الملك عبدالعزبز - جلة - المعلكة العربية السعودية المبية \\ a_alsaati@hotmail.com \\ المستخلص. تم في هذا البحث التعليل الاقتصادي لضوابط المبادلات

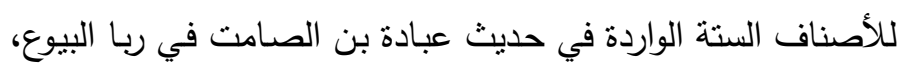

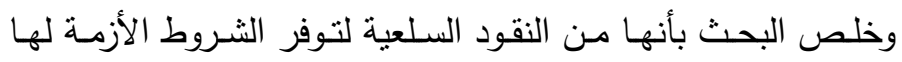

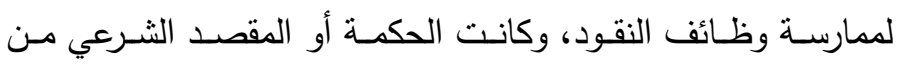

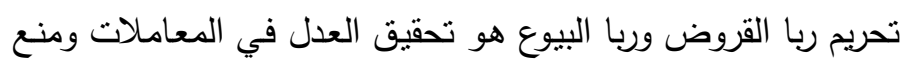

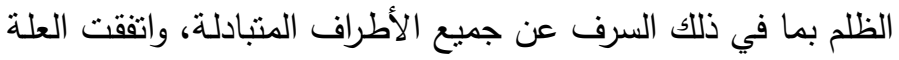

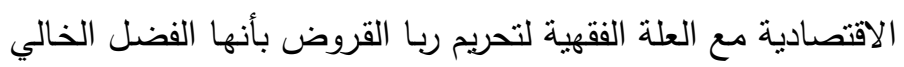

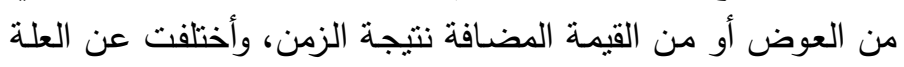

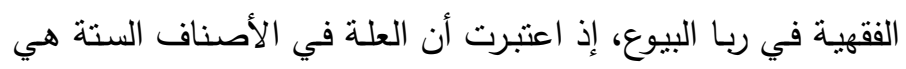

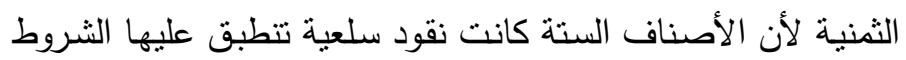

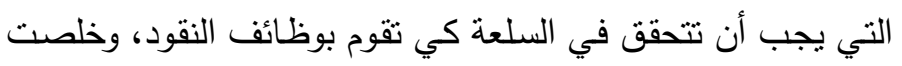

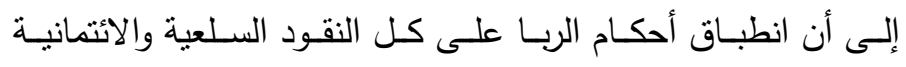

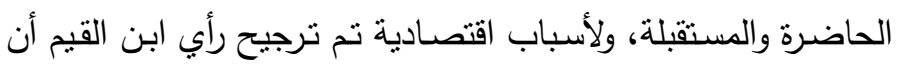

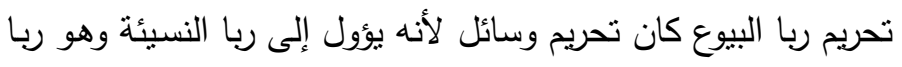 \\ القروض والذي قصد بالتحريم.
}




\section{الصعوية في تحديد الربا وعلته}

يعتبر الربـا أو الفائدة مـن الموضـوعات التي يختلف حولها الاقتصساديون وكذلك الفقهاء، ولا توجد إلى الآن نظريات رصينة تفسر سعر الفائدة بطربقة منطقية تتفق

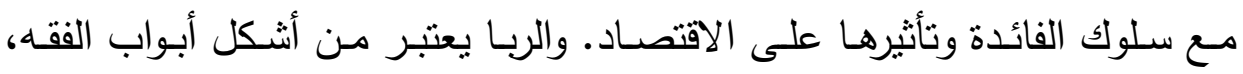
ويقول عمر بن الخطاب رضي الله عنه (من آخر ما نزل آية الربا، وأن رسول الله قبض قبل أن يفسرها، فدعوا الربية والربا)(') يقول ابن كثير : (باب الربا من أشكل الأبواب على كثير من أهل العلم)(r)، ويقول الثاطبي: (إن الربا محل نظر يخفي وجهه على المجتهدين، وهى من أخفى الأمور التي لم يتضح معناها إلى اليوم)(ऍ). والربا أو الفائدة ظاهرة اقتصادية هامـة في الأدبيات الغربية وتلعب دورًا مهرًا في النظرية الرأسمالية وفي السياسات الاقتصادية، وسوف تستخدم في هذه الدراسـة الأدبيـات الخاصـة بسعر الفائدة في النظريـة الغربيـة لتفسير ظـاهرة الربـا وترجيح مقاصد وعلة تحريمه، ذلك أن تحربم الثربعة للربـا وسد المنافذ إليه جاء لتحقيق مصـالح العبـاد، وإذ يقول ابـن القيم: (فـان الثـربعة مبناهـا وأساسـها على الحكم ومصالح العباد في المعاش والمعاد، وهي عدل كلها ورحمة كلها، ومصالح كلها، وحلة كلها)(؛)، وفي تفسير الأحاديث الواردة في الربا سوف يتم استخدام المفهوم الاقتصـادي لظـاهرة الربـا للوصـول إلى المقاصـ الاقتصـادية التي يمكن أن تفهم

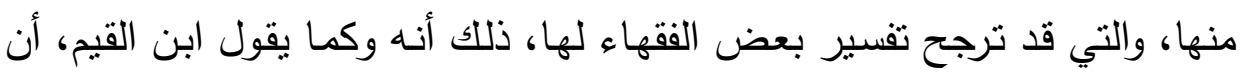

(1) محمود الألوسي (د.ت.) روح الدعاني في تفسير القرآن العظيم والسبع الدثاني، بيروت: دار إحياء

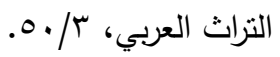

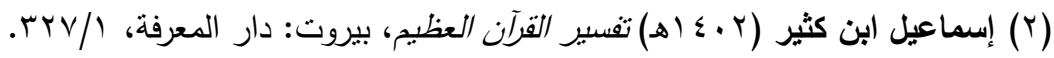

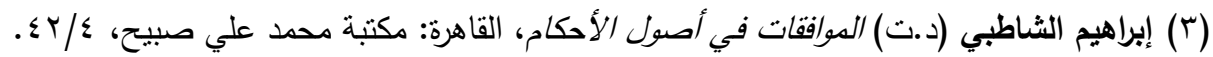

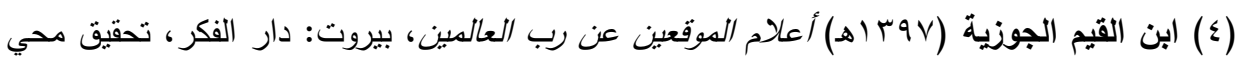


العبرة بالقصد لا بالألفاظ ويقول: (ومن تدبر مصـادر الشرع وموارده تبين لله أن

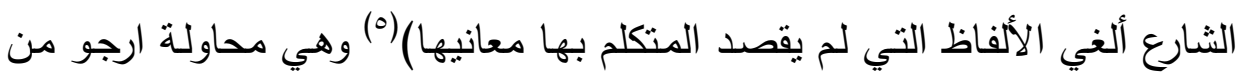
الله أن يكتب لها التوفيق.

\section{العلة والحكمة والمقصد الثرعي}

العلة: نطلق على الوصف الظاهر المنضبط والذي يحصل من تطبيق الحكم عليه مصلحة، وتعرف بالوصف المعرف للحكم والمؤدي اليه، كتحريم الزيادة في القرض يؤدي إلى تحقيق مصلحة العدل ورفع الظلم، وتحريم الإسكار يؤدي إلى تحقيق مصلحة حفظ العقل .

الحكمة: هي مـا يترتب على التشريع من جلب المصـالح وتكميلها، أو دفع المفاسد وتقليلها، كما تطلق الحكمة على المقصد الكلي أو المصلحة الإجمالية، كمصلحة استقرار المعاملات وتحقيق العدل وحفظ النفس ورفع الحرج. المقاصد الشرعية: هي جملة ما أراده الشارع الحكيم من مصـالح تترتب على الأحكام الثرعية كمصلحة استقرار المعاملات من تحريم الغرر ومصلحة التقوى

من الصوم ومصلحة تحصين الفروج من الزواج(؟).

\section{العدل هو المقصد من تحريم الربا:}

العدل هو الهدف للنظـام الاقتصـادي الإسـلامي، لأنه الهدف التي أرسلت الرسل

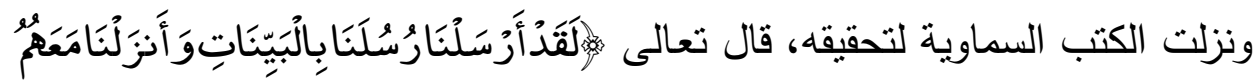

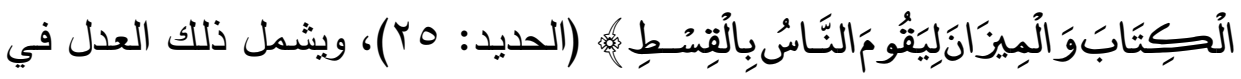

(0) ابن القيم الجوزية (Vو اهـ) أعلام الموقعبن عن رب العالمبن، بيروت: دار الفكر، تحقيق محي

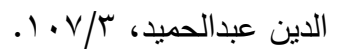

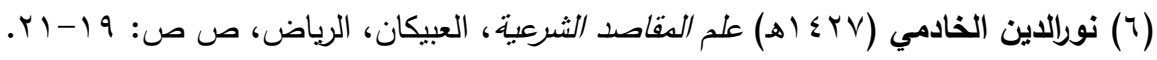




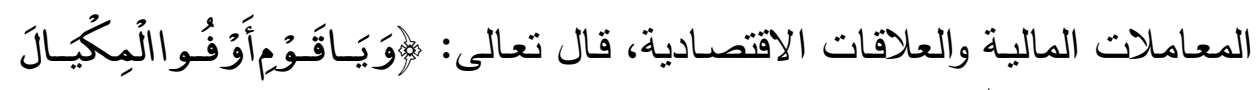

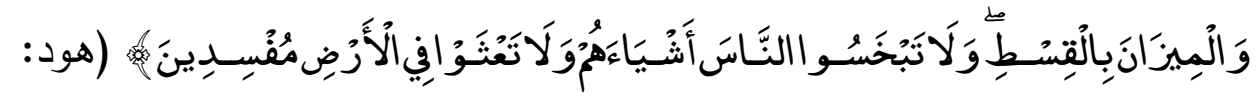

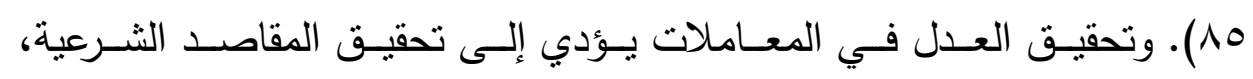

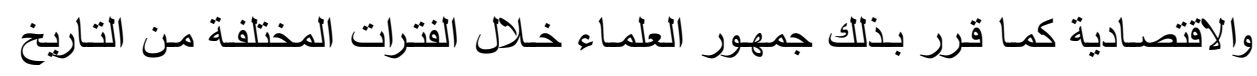

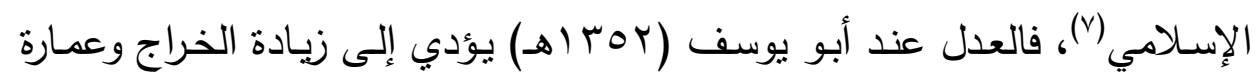

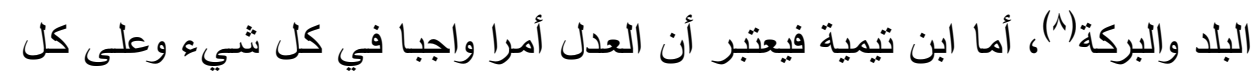
أحد، والظلم محرم في كل شيء وعلى كل أحد(9)، ويعتبر ابن خلدون أن الظلم مخرب لكل عمران وأنه لا يمكن لبلد أن ينطور بدون عدل(·'). وفي حكمة تحريم

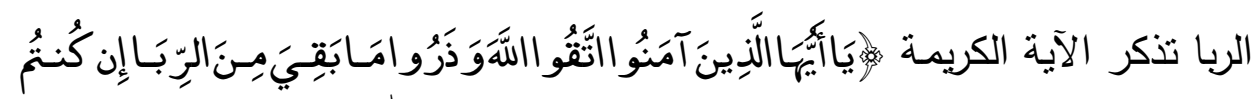

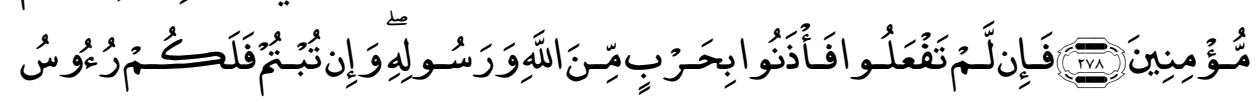

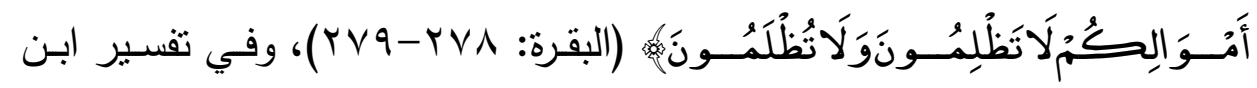

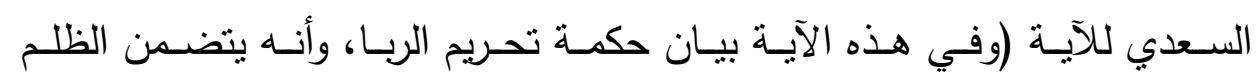

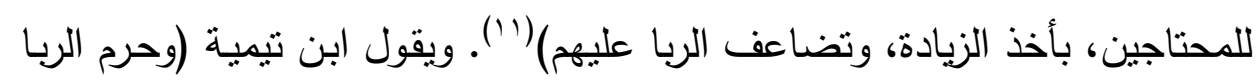

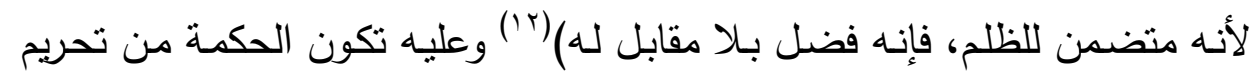
الربا بكل أنواعه هو تحقيق المقصد الشرعي وهو مصلحة العدل وتحريم مفسدة الظلم.

(V) محمد عمر شابرا (TYY (ه) مسنقبل علم الاقتصاد من الدنظور الإسلامي، دار الفكر ، ص ص: $.111-1 \cdot v$

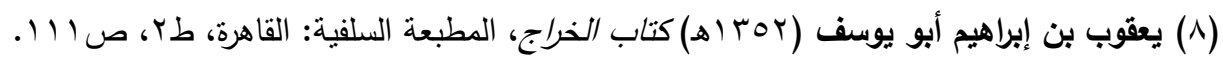

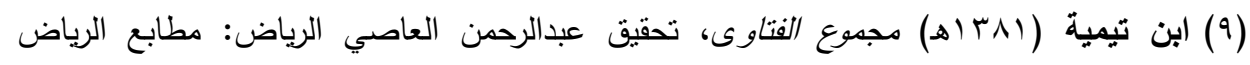
170/11

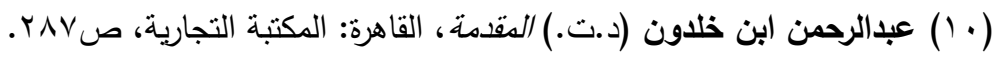

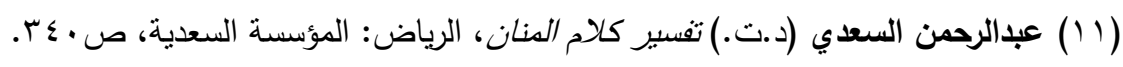

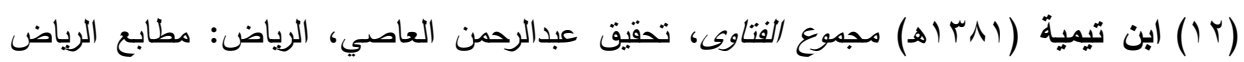
.rะ) $/ \mathrm{r}$. 


\section{النقود هي موضع ريا النسيئة}

الربا أو الفائدة وهي من أنواع الربا في الاقتصاد المعاصر هي ظاهرة نقدية،

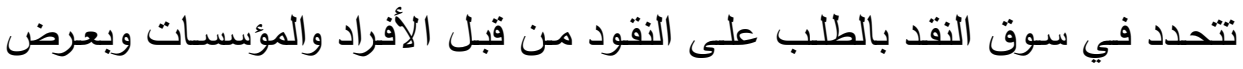
النقود من قبل السلطات النقدية، عرف كينز سعر الفائدة بأنه الثمن الذي يدفع

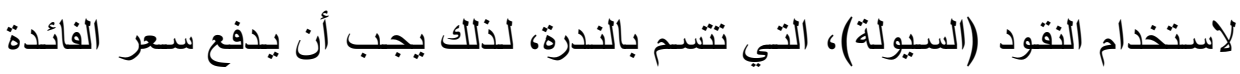

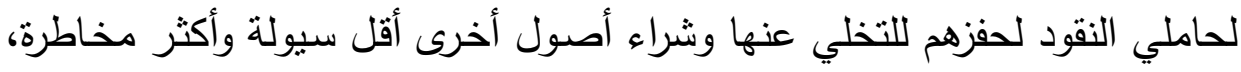

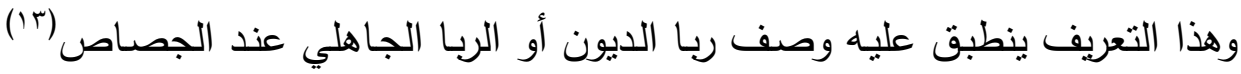

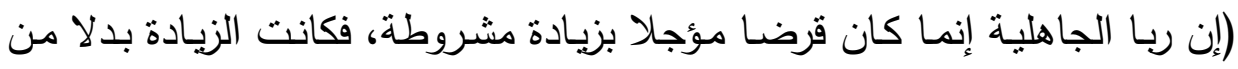

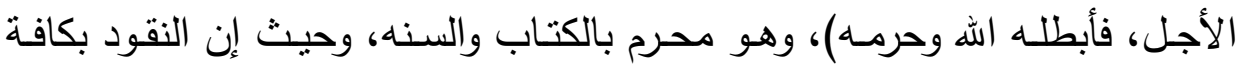

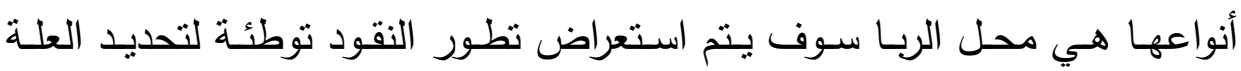
الاقتصادية لتحريم ربا الفضل والنسيئة.

تعريف النقود: النقود مؤسسة اقتصادية اجتماعية وجدت مع وجود التعامل

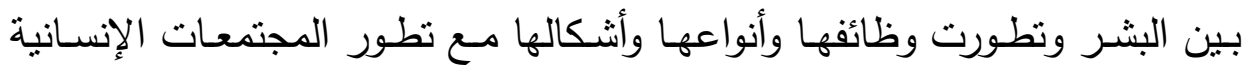

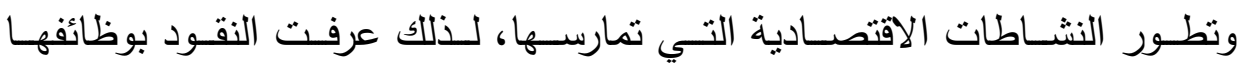

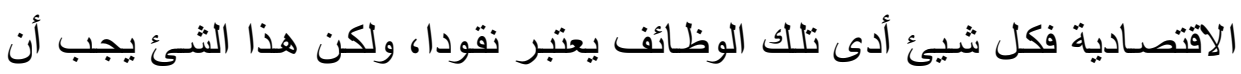
تتوفرفيه كل أو بعض الثروط وهي (1) (1):

1- أن يحظى بقبول عام، أي يقبل بـه الأفراد بـه كبديل أو ثمن لسلعهم أو

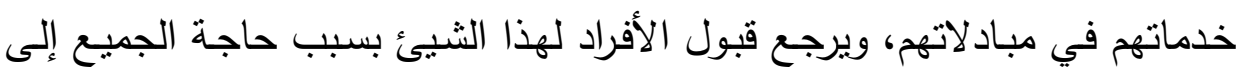

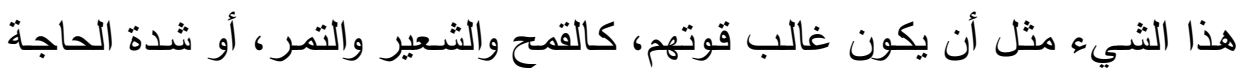

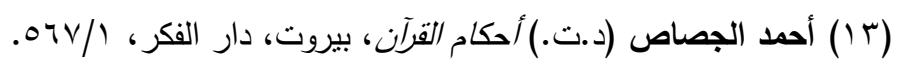

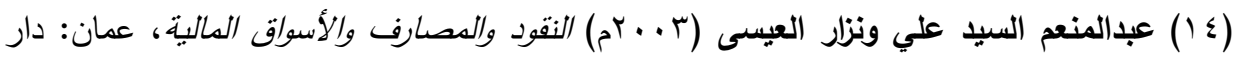

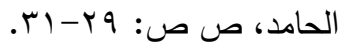


إلبه مثل الملح لسكان الصحراء أو بسبب العرف أو بسبب ندرة هذا الثيء ورغبة الناس فيه مثل الذهب والفضـة وأصداف الزينة، وقد يقبل من الجميع بقوة القانون منتل النقود القانونية

r- أن تكون وحداتها متجانسـة ومتماتلـة، فـإن كانت سلعة يجب أن تكون متلية وليس قيمية وذلك حتي يمكن أحلالها بجنسها وتكون قيمة وحداتها متقاربة فلا يمكن للحيوانات الحية، أو الفاكهة أن تكون نقودا بسبب عدم مساوات وحداتها. ب- أن يغلب الظن أن تكون منوافرة بكميات مناسبة، فـلا تكون وفيرة جدا فتفقد قيمتها التبادلية ولا تكون شحيحة لا بمكن الحصول عليها إلا بمشقة كبيرة. ع- أن تكـون قابـــة للقسـمة أي يمكـن تقسـيمها وبالتـالي صـالحة لتسـوية المعـاملات الكبيـرة والصـغير ، منّل الذهب والفضـة أو القــح والثـعير مـن الســع الغذائية.

0- أن تكون خفيفة الوزن حتى يسهل حملها ونقلها.

ج- أن تكون قابلة للتخزين والإدخار لفترة زمنية مناسبة وذلك حتى تمارس وظيفة خزن القيمة، فلاتكون سريعة التلف، فلا تصلح الخضسار والفواكه الظازجة أن نكون نقودا لأنها غير قابلة للتخزين لفترة طويلة دون تكاليف مرتفعة.

\section{وظائف النقود}

تؤدي النقود إلى تخفيض نفقات التبادل، وتوفير الأسـاس لحسابات اقتصـادية رشـيدة، كمـا تـوفر أسـباب دفـع النمـو الاقتصـادي بقدرتها على تـوفير المـدخرات اللزمة للتقدم الفني والتكوين الرأسمالي (10). 
إذا تـوفرت الثـروط السـابقة أو غالبيهـا فـي أيــة سـلعة يمكـن أن يصـطلح المجتمـع على جعلها نقود، وتمـارس النقود في النظام النقدي الإسـلامي كما في الني النظم الأخرى الوظائف التالية(بان (1):

1- مقياسًا للقيمة: يقول ابن العربي في تحريم كسر الدراهم والدنانير (لأنها

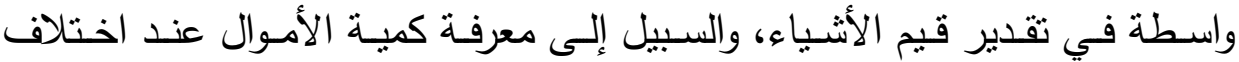

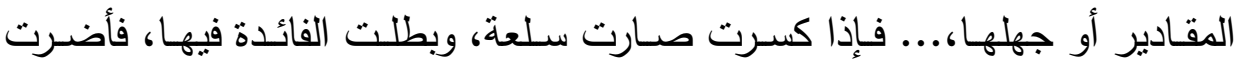
بالناس، فلأجله حرمت)(v'). ويقول ابن تيمية: (إن المقصود من الأثمان أن تكون

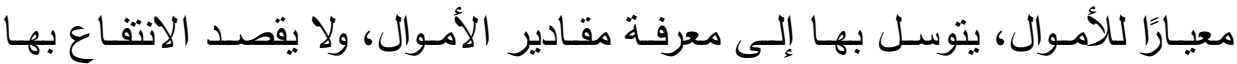

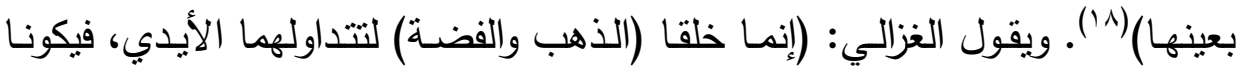
حاكمين بين الناس، وعلامة للمقادير ، مقومة للمراتب)(9 (').

r- واسطة للتبادل: يقول ابن همام (وقولهم في النقدين، خلقًا للتجارة: إنهما خلقا للتوسط بهما إلى تحصيل غيرهما، ...، فخلق النقدان لغرض أن تستبدل بهما ما تتدفع به الحاجة بعينه بعد خلق الرغبة فيها، فكانت للتجارة خالقة)(·r). ب- مخزنًا للقيمة: يؤدي استخدام النقود في التبادل إلى فصل عملية البيع عن الثراء، التي تتم في آن واحد في عملية التبادل بالمقايضـة، لذلك كان يجب إبـ على النقود في حالة استخدامها كوسيلة للتبادل أن تكون فيها خاصية تخزين القيمة إلى حين الحاجة إليها. وهذا لا يعني اكتتازها. يقول: ابن خلدون (إن الله تعالى خـالق الحجرين المعدنيين مـن الذهب والفضـة، قيمـة لكل متمـول، وهمـا الذخيرة

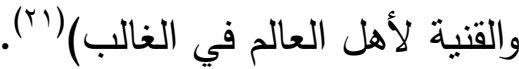

Goldfeld, S.M. and Chandler, L.V. (1973) The Economics of Money and Banking, 8ed. (1 7) Harper \& Row, Publishers, New York, pp: 7-10.

$$
\begin{aligned}
& \text { ( IV) }
\end{aligned}
$$

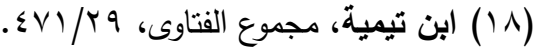

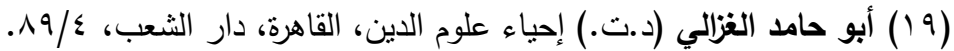

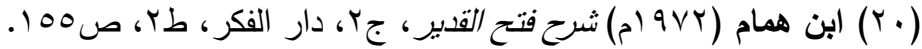

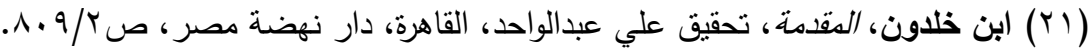


ع - معيارًا للمدفوعات المؤجلـة: الديون والالتزامـات المؤجلـة غالبَّا مـا بتفق بردها بوحدة الحساب نفسها التي تستخدم كوسيط للتبادل، لذلك يجب أن تتصف

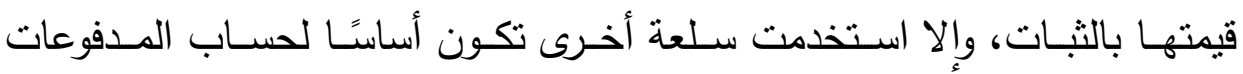
المؤجلة كالذهب. ويقول في ذلك ابن القيم: (والثمن هو المعيار الذي يعرف بـه

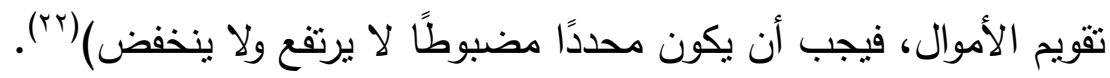

\section{أنواع النقود}

يمكن التمبيز بين نوعين من النقود وهما:

\section{أولا: التقود السلعية}

وهي سلع تحظى بقبول عام للحاجة إليها وتستخدم كوسيلة للتبادل، ولها قيمة تبادلية وهي قيمتها كوحدة للنقد في مقابل السلع والخدمات الأخرى، كما لها قيمة

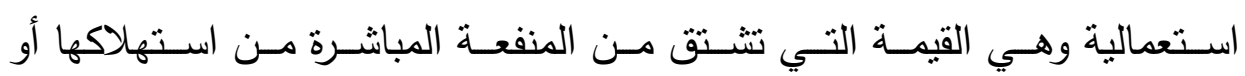
استخدامها، ويدخل في جملة النقود السلعية، النقود الممثلة وهي نقود ورقية ممثلة لسـلعة مثنل الـذهب أو الفضـة، وقد تطـورت النقود الممثلــة مـن النقود السـلعية، وتتوعت هذه النقود بتطور المجتمعات، ففي الاقتصاد الذي تسود فيه المقايضات يختار المجتمع بعض السلـع والتي تتوفر فيها بعض الثروط التي يجب أن تتوفر في النقود لتصبح نقودا، ففي المجتمع النبوي كانت النقود يغلب عليها أن تكون

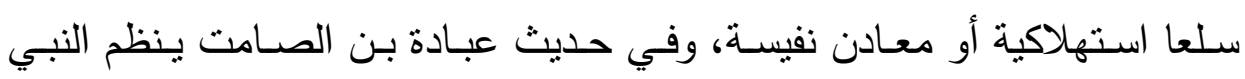
(صلى الله عليه وسلم) طرق التبادل المشروعة في هذه السلع والتي كانت تستخدم في الغالب كنقود سلعية حيث يقول: (الذهب بالذهب، والفضة بالفضـة، والبر بالبر والثعير بالثعير ، والتمر بالتمر والملح بالملح، مثنلا بمثل سواء بسواء يدا بيد.فإذا 
اختلفت هذه الأصناف فبيعوا كيف شئنم إذا كان يدا بيد)(r(م) إن كل سلعة من الأصـناف السـتة في الحديث لها اسـتعمالين، في الأطعمـة الـواردة في الحديث تستعمل كسلعة استهلاكية ويقصد منها الطعام، وفي الذهب والفضـة يقصد منها القنيـة، والاستتعمال الثاني تسـتخدم الأصـناف السـتة كنقود سـلعية في الأصـناف الأربعة ونقود معدنية سلعية في الذهب والفضة، ويختلف حكم تبادل هذه الأصناف والأصناف المماثلة لها حسب النية أو القصد من استخدامها، فيجري فيها الربا إذا استخدمت كنقود ولا يجري فيها الربا إذا استخدمت كسلعة، ويقول ابن القيم: (قد تظاهرت أدلة الشرع وقواعده على أن المقصود في العقود معتبرة، وأنها تؤثر في صحة العقد وفساده وفي حله وحرمته، بل وأبلغ من ذلك، وهي أنها نؤثز في الفعل

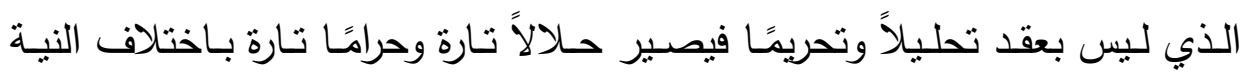
والقصد، كما يصير صحيحا تارة وفاسدا تارة باختلافهما)(عَ)، ويشير محمد رشيد رضا، إلى كون الأصناف الستة في الحديث أنها نقود، قوله (والمذهب الوسط أن الأجناس الستة المذكورة في الحديث كانت ولا تزال معيارًا لاثمان وأصسول الاقوات لأكثر البشر) إلى أن يقول (فإذا وجدت العلة في نقد آخر غير الذهب والفضـة وفي قوت آخر غير البر والثـعير والتمـر والملـح، صـح قياسـها على الأجنـاس الستة، لحلولها محلها، وانطباق حكمة النتريع على ذلك)(ro(r).

\section{النقود الائثمانية}

والنقود الائتمانيـة هي النقود التي لاتستمد قيمتها من مـادة النقود، التي قد تكون ورقا أو حسابا في مؤسسـة مالية أو في بطاقة بلاستيكية، بل تستمد قيمتها

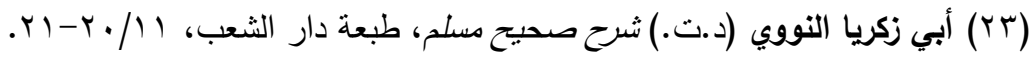

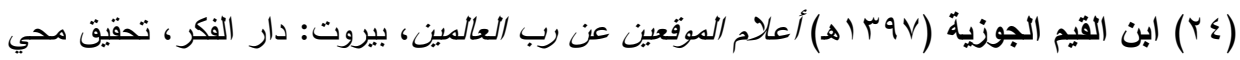

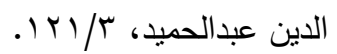
(Y0) محمد رشيد رضا (د.ت.) بير الإسلام وأصول التشريع، مصر : مطبعة المنار ، ص آT. 
مـن القوة الثـرائية أو القيمـة المخزنـة في هذه النقود التـي يمكن تبادلهـا بالســع

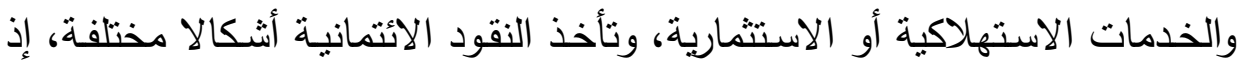
قد تكون نقود ورقيـة تصدرها وزارة الماليـة أو البنك المركزي أو تكون الحسـابات الجارية في المؤسسات المالية (التعريف الضيق للنقود) وقد يتت التوسع في تعريف النقود ليضـم الحسـابات الإدخاريـة والاسـتمارية القصيرة الأجل وينضـم إلى ذلك النقود الالكترونيـة (التعربـف الواسـع للنقود)، وتتوفر في النقود الائتمانيـة معظم الشـروط التي يجب أن تتوفر في النقود، كما تقوم بجميع وظـائف النقود، وفهم

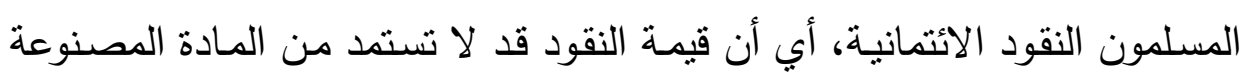
منها، وإنما في التقة فيها، فقد فكر عمر ابن الخطاب أن يجعل النقود من جلود الأبل، وقد روى البلاذري قال: (لقد كان عمر ابن الخطاب قال: همدت أن أجعل الدراهم من جلود الأبل، فقيل له إذن لا بعير . فأمسك)(بَ)، وجاء في مدونة الامام مالك (لو أن الناس أجازو بينهم الجلود حتى يكون لها سكة وعين لكرهتها أن تباع بالذهب والورق نظرة)(rV)، ويقول ابن تيمة في الفتاوي: (وأمـا الدرهم والدينار فما يعرف لله حد طبيعي ولا شرعي، بل مرجعه إلى العادة والاصـلاح، وذلك لأن في

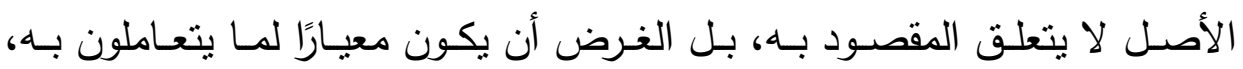
والدراهم والدنانير لا تقصد لنفسها بـل هي وسيلة إلى التعامـل بها ولهذا كانت

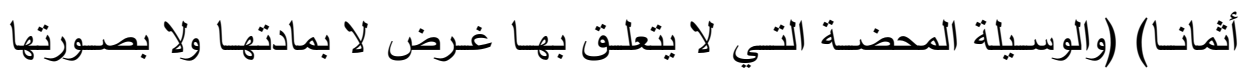

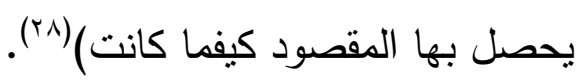

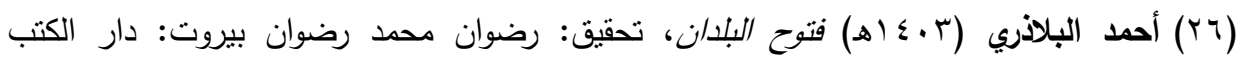

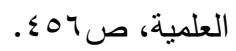

(YV) الإمام مالكك بن أنس (د.ت.) المدونة الكبرى، برواية سحنون بن سعيد التتوخي، بيروت: دار

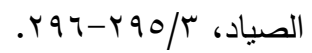

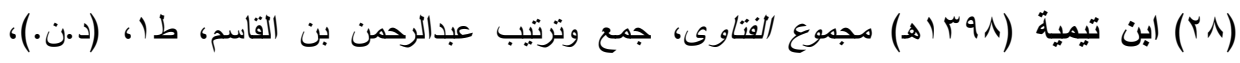
.ro1/rq 
ويجري الربا في النقود الأتثمانية لتوفر علة الثمنية ويقول ابن منيع: (إن الورق النقدي (وينطبق ذلك على كل النقود الائتمانية نقد قائم بذاته) (وسر قبوله ثقة الناس به كقوة شرائية مطلقة، بغض النظر عن أسباب حصول الثقة بـه. وحيث إن الورق النقدي لـه خصـائص النقدين الـذهب والفضــة مـن أنـه ثـن (وكذللك سـائر النقود الائتمانيـة)، وبـه تقوم الأشياء والنفوس تطمئن بتموله وادخاره، فإن لـه حكم النقدين الذهب والفضة في جريان الربا بنوعيه فيه، كما يجري فيهما قياسا عليهما، لاندراجه تحت مناط الربا في النقود وهو الثمنية)(وج) وقد أقرت المجامع لفقية النقود الورقية وأجرت عليها أحكام النقود في الصرف والربا والزكاة.

الربا وأنواعه وعلة تحريمه

تعريف الربا

تعريف الربا: الربا في اللغة الزيادة، ربـا الثيء أي زاد ونمـا، أربيته: نميته، وربا المال، إذا زاد وارتفع، وهناك ثلاث اتجاهات في تعربفه شرعًا، من الفقهاء من أكد على ربـا القروض باعتبـاره هو الربـا، ومنهم ابـن كثير الذي يعرفهه شـرعا:

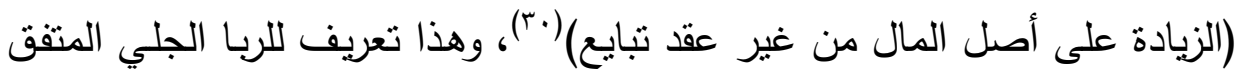
عليه. ومنهم من أكد على ربا البيوع، ذللك لأنه هو الذي يقع فيه الخلاف، منهم

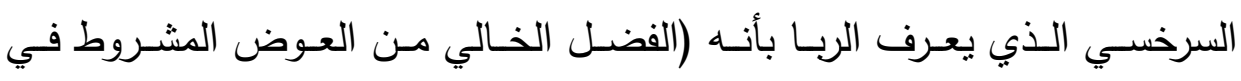
البيع)('ب)، والثربيني الذي يعرفه بأنه (عقد على عوض مخصوص غير معلوم

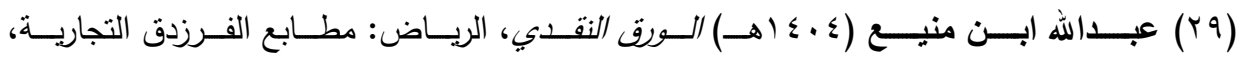
ص ص: عأ $110-10$.

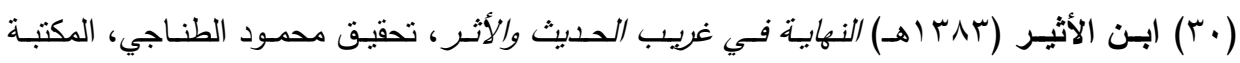

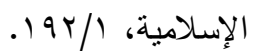

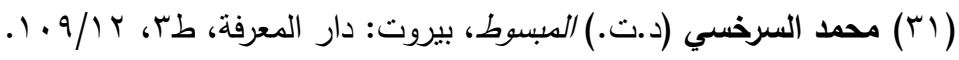




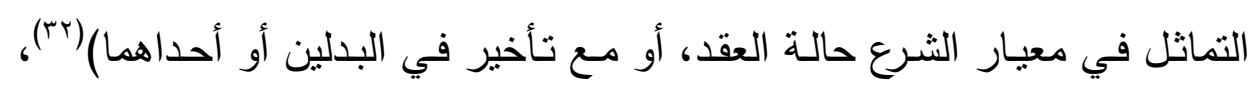

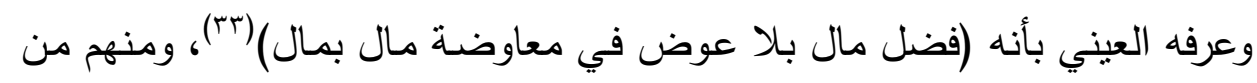
شمل التعريف ربا الديون وربا البيوع، فابن العربي عرف الربا (بأنه كل زيادة لم

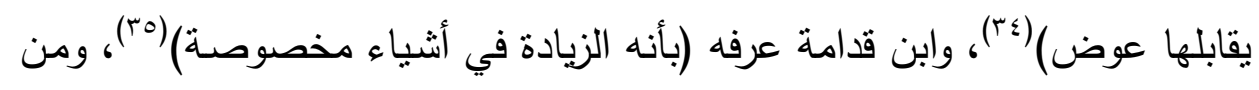
الأحناف عرفة العيني (فضل مخصوص مستحق لأحد المتعاقدين خال عما يقابله

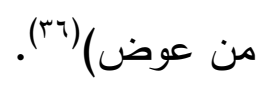

يمكن تقسيم الربا إلى نوعين:

أولا: ربا الاين

ويعرف أيضا بربا النسيئة أو ربا القروض، أو الربا القرآني أو ربا الجاهلية أو الفائدة في المعاملات المالية، وهو الزيادة التي تتقرر في الذمة في الدين الناشـئ عن سلف أو بيع نظير الأجل، ويأخذ صور عدة، منها: ا- القرض بزيادة نظير الأجل، وهو ما وصفه الجصاص بقوله: (الربا الذي كانت العرب تعرفه وتفعله إنما قرض الدراهم والدنانير بزيـادة على مـا استقرض وهل على ما يتراضون به)، وهذ يتفق مع وصف كينز للفائدة حيث عرف كينز الفائدة

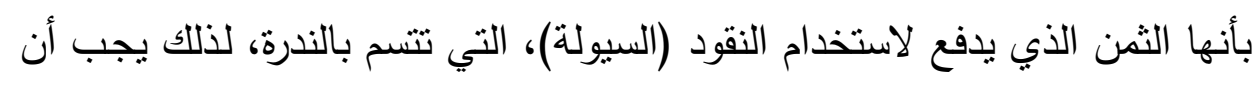

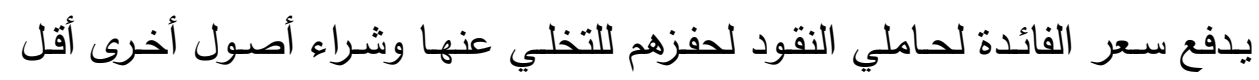
سيولة وأكثر مخاطرة.

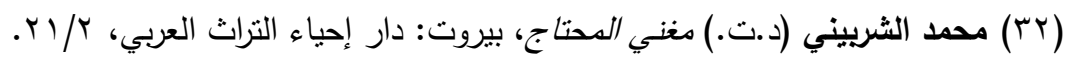
(

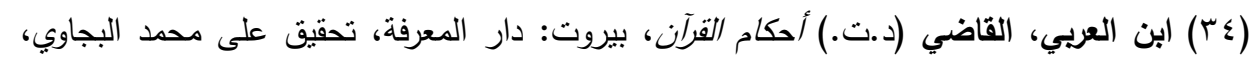

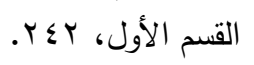

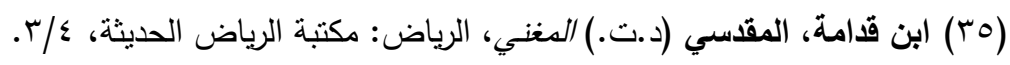

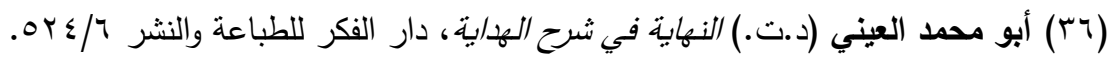


r- الفائدة الجزائية وهي الفائدة أو الربا المترتب على تأخير دفع الدين في أجله، ووصفه الطبري بقوله: (يبيع الرجل البيع إلى أجل، فإذا حل الأجل ولم يكن عند صاحبه قضاء، زاده وأخر عنه)(rv(

ب- الفائدة المركبـة أو الربـا المركب، ووصـفه الألوسـي بقولـه: (كان الرجل

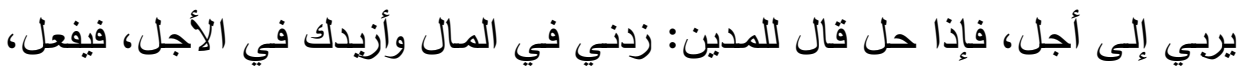

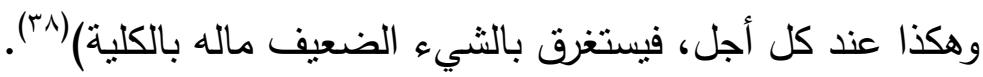

ع- دفعات الفائدة الدورية على القرض الذي يكون في شكل سند حكومي أو خاص ذو دفعات دورية، وإعادة جدولتها في حال التعثز ، يصف ذللك الفخر الرازي بقوله: (يأخذون المـال، على أن يأخذوا كل شـهر قدر معينا، ويكون رأس المـال باقيا، ثم إذا حل الدين طالبوا المديون برأس المال، فإذا تعذر عليه الأداء، زادوا في

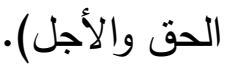

\section{الإجماع على تحريم ربا الدين}

نقل الإجمـاع بـين العلمـاء على أن آيـات الربـا نزلت في بيـان تحريم رب

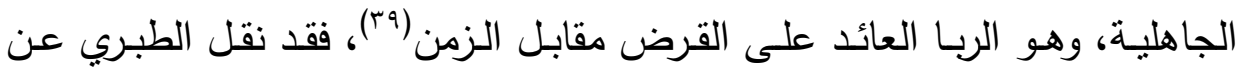
مجاهد أنـه قال في الربا الذي نهي عنه: (كانوا في الجاهليـة يكون للرجل على

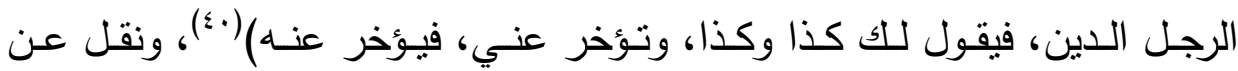

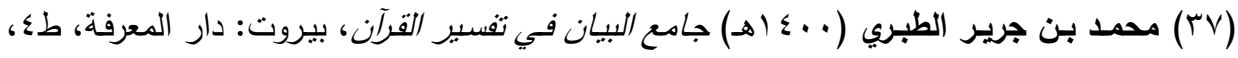
.TV/ $\mathrm{T}$ (T^) محمود الألوسي (د.ت.) روح الدعاني في تفسير القرآن العظيم والسبع الدثاني، بيروت: دار إحياء

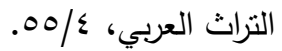

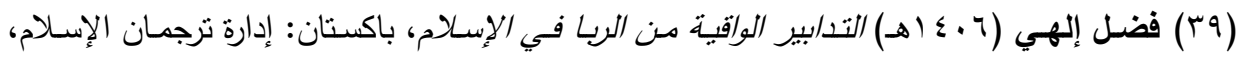
ص صזr.

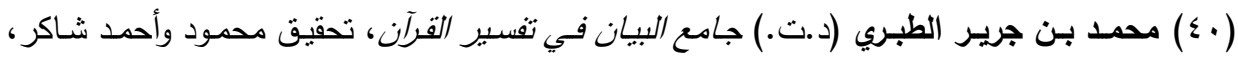

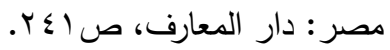


الجصـاص قوله: (إنـه من المعلوم أن ربـا الجاهليـة إنما كان قرضـا مؤجلا بزيـادة مشروطة فكانت الزيادة بدلا من الأجل)، ويعتبر كثير من العلماء أن ربا القروض هن إنه هو الربا الحقيقي المقصود بالتحريم، وإنما حرم ربا البيوع تحريم وسائل، وفي ذلك هلك يقول ابن القيم بعد تقسيمة للربا إلى ربا جلي وربا خفي: (أما الجلي فربا النسيئة، وهو الذي كانوا يفعلونه في الجاهلية، مثثل أن يؤخر دينه ويزيده في المال، وكلما

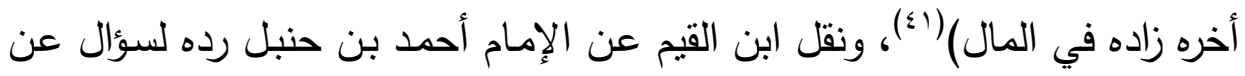
الربا الذي لا شك فيه قوله: (هو أن يكون له دين فيقول له: أتقضي أم تربي؟ فإن

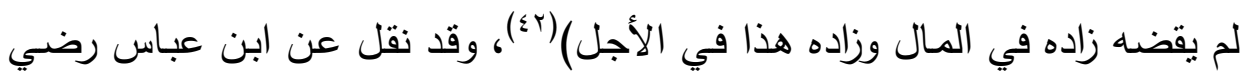

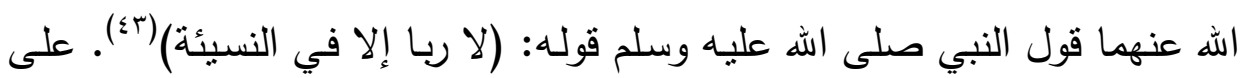
الرغم من ذلك ومن أهميته (الفائدة أو الربا) المعاصرة إذ أنه المحور الذي يدور عليه النظام الرأسمالي أو نظام السوق والنظربات الاقتصادية الكلية والجزئية وعليه تبنى السياسات الاقتصادية وأدواتها الذي يتم بها التحكم والتوجيه في الاقتصادات المعاصرة الذي يكاد يسود العالم بما فيها الدول الإسـلامية، إلا أن كثير من كتب لتب الفقهـ القديمـة والحديثة قد لـم تتوسـع في الحديث عنـه إلا مـن إثــارات ولمحسات مجملة، مقارنة بتفصيلهم لربا الفضل أو رب البيوع، وهذا يوجد الحاجة إلى توجيه

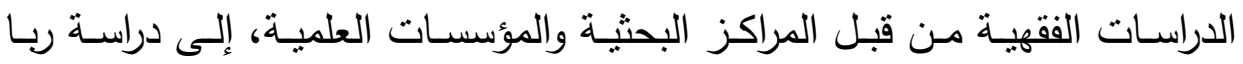

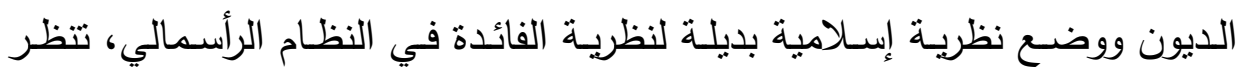
للسلوك المالي وتضـع نظريـة للتمويل الإسـامي تفسر حوافز التدفقات المالية بين الوحدات الاقتصـادية في اقتصـاد إسـالامي وتوجد أدوات ماليـة يمكن إن تسـتخدم لإدارة النشاط الاقتصادي في اقتصاد إسلامي.

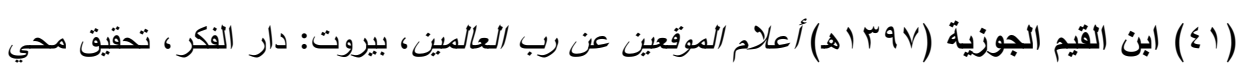

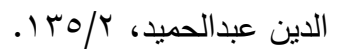

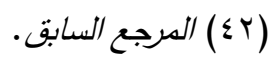
(rاء) محمد بن إسماعيل البخاري (د.ت.) صحيح البخاري، الرياض: رئاسة إدارة البحوث العلمية

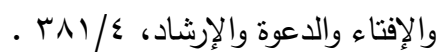


على الرغم من قلة الاهتمام الذي حظي به ربا الديون في الأدبيات الفقهية إلا

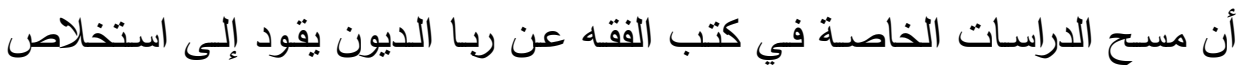

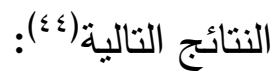

هنالك إجماع بحرمة ربا القروض دون أن يثذ عنه أحد من أهل العلم. • كان اختلاف العلماء في تصنيفه، فابن رشد جعله مستقلا، والحقه الرملي والزركثـي بربا الفضل، والحقه ابن القيم بربا النسيئة، ولكن جميعهم يرونه يندرج تحت النصوص القرآنية التي تحرم الربا.

منهم من جعله قسما مستقلا نص على أنه المقصود بربـا الجاهلية في

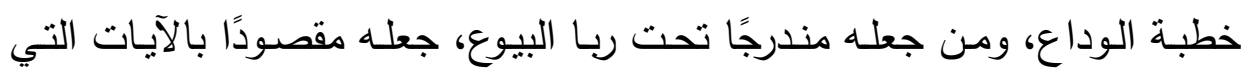
تحرم الربا.

•الذين الحقوه بربـا الفضل نظروا إلى الزيادة المحرمة لأنها أسـاس التحريم ومرده، والذين الحقوه بربا النسيئة نظروا إلى الباعث إلى هذه الزبادة وهو الأجل وهو مبرر الزيادة

اقتصاديات ربا الديون

القيمة المضافة

تعرف القيمة المضافة بأنها الزيادة في قيمة المخرجات التي تضيفها المؤسسـة عن قيمة مدخلاتها وتحسب بطرح تكلفة المدخلات (عناصر الإنتاج) من القيمة الإجمالية لمنتجاتها النهائية، وتستخدم طريقة القيمة المضافة لحساب الناتج القومي الإجمـالي بحسـاب القيمـة المضـافة لكل منشـاة في الاقتصـاد (0)، وتختلف القيمـة ولهـ

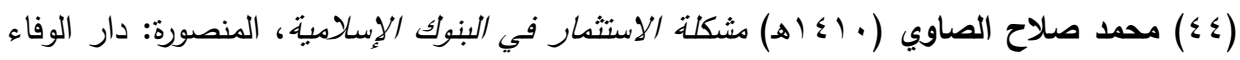

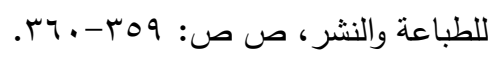

Lipsey, R.C. and Stiener, P.O. (1978), p. 461. ( $($ O) 
المضـافة عن الإنتاجية الحديـة، ويقصد بالإنتاجية الحديـة لعنصر الإنتاج، الزيادة

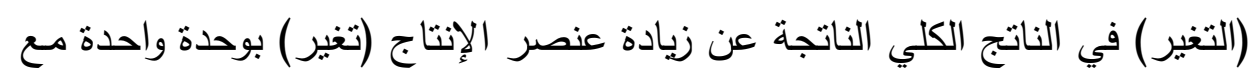
افتراض بقاء عوامل الإنتاج الأخرى ثابتة.

يؤدي استخدام النقود إلى تخفيض نفقات التبادل، وتوفير الأسـاس لحسابات اقتصـادية رشـيدة، كما تـوفر أسـباب دفـع النهو الاقتصـادي بقدرتها على توفير

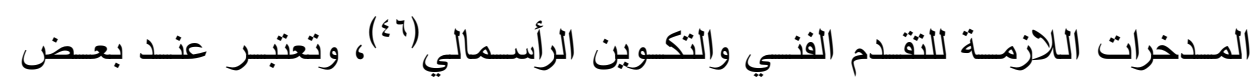

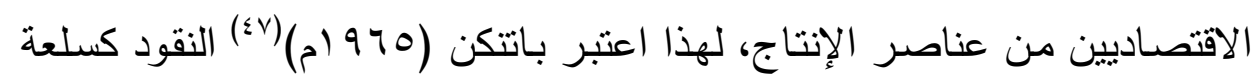

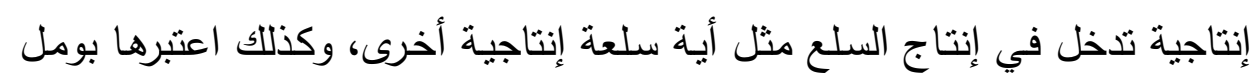
(904 (م)(^) في نظرية الطلب على النقود من أجل المعاملات في طريقة نظرية

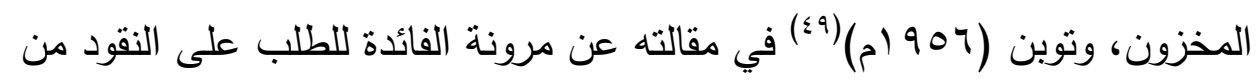

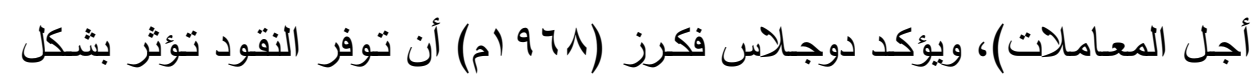
كبير على الحد الأمثل لإنتاج وعلى كمية عناصر الإنتاج المستخدمة في العملية الإنتاجية وتعتبر التكلفة الحدية لاستخدام النقود (سعر الفائدة الدفوع للحصول على

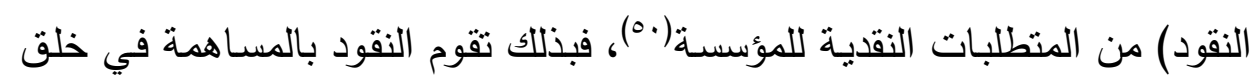
القيمة المضافة في العملية الإنتاجية من وجهة نظر النظربة الغربية، فيكون مبررًا لدفع الفائدة على النقود.

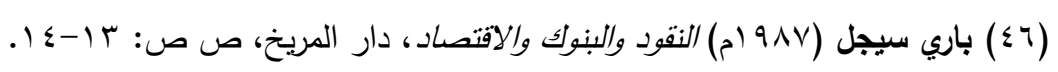

Patinkin, Don (1965) Money, Interest, and Prices, Harper \&Row publishers, New York, ( $\{\vee$ ) p. 150.

Baumol, W.J. (1952) The transaction Demand for Cash: An Inventory Theoretical $\left(\sum \wedge\right)$ Approach, Q.J. of Econ. LXVI, pp: 545-56.

Tobin, J. (1956) The Interest Elasticity of Transation Demand for Cash, R. of Econ. and ( $१$ १) Stat., XXXVIII, pp: 241-47.

Vickers, Douglas (1968) The Theory of the Firm: Production, Capital, and Finance, New (०•) York: McGrow-Hill, p. 133. 


\section{الفائدة النقاية (ريا القروض)}

ربا القروض أو الفائدة وهي ظاهرة نقدية، تتحدد في سوق النقد بالطلب على النقود لأجل المضاربة وبعرض النقود من قبل السلطات النقدية، عرف كينز سعر فران

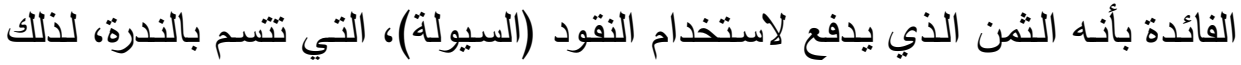

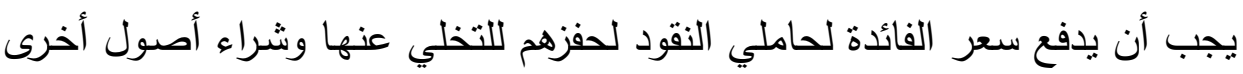

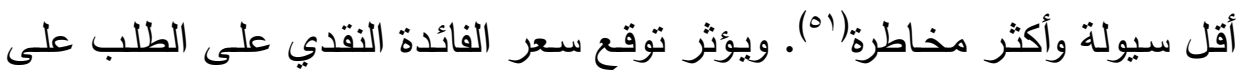

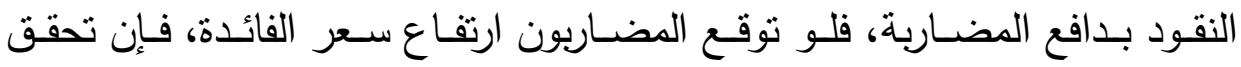

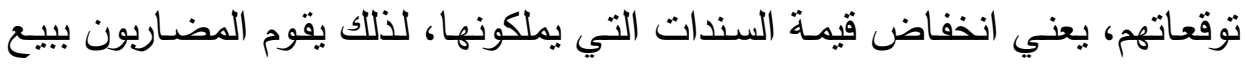

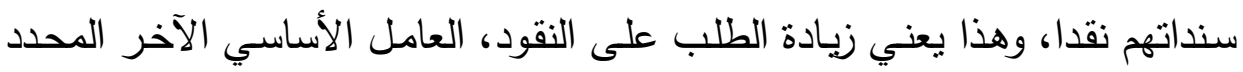

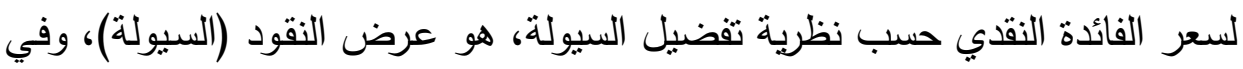

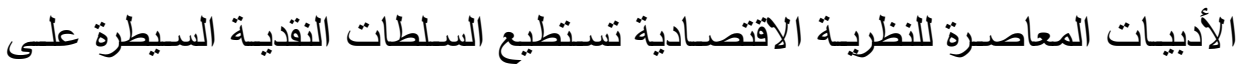

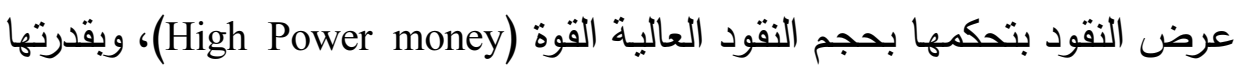
على استخدام أدوات السياسة النقدية في السيطرة على مقدرة البنوك في خلق النقود.

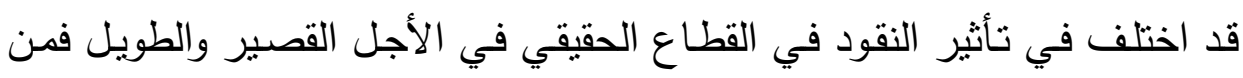
يعتقد بحيادية النقود لا يرى تأثثر لها ولكن من يرى بعدم حيادية النقود يرى بأن

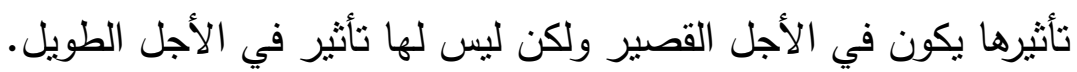

\section{الريا وإعادة التوزيع والأزمات الإتصادية}

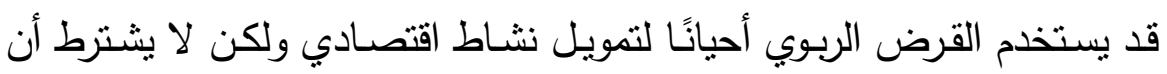

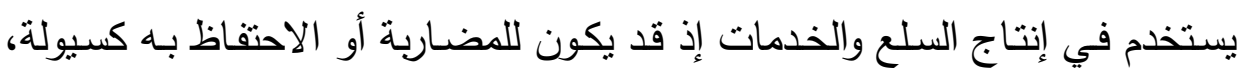
وفي هذه الحالة لا يتسبب القرض في خلق قيمة مضافة لأنه لم يستخدم في عملية إنتاجيـة، ولكن مدفوعات الفوائد لتلك القروض تؤدي إلى تحويل القيمـة المضـافة

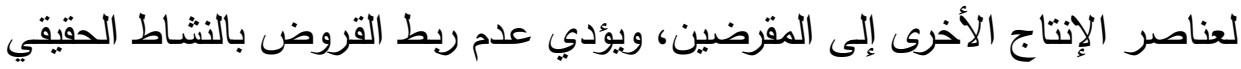


إلى التوسـع في الاقتراض وينشـأ مـا يسـى بـالهرم المقلوب، والذي فيه يكون حجم القرض أضـعاف الضـمانات التي تغطى بها تلك القروض، والتي غالبا مـا تكون أصسول حقيقيـة، وقد وصـلت الديون في الاقتصساد الأمريكي عـام ^ . . بم ثـلاث

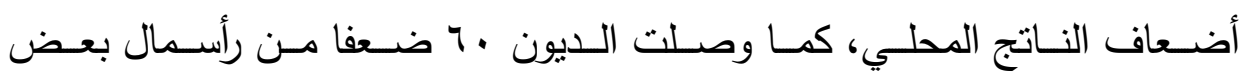
البنـوك(or)، وحيـث إن الفوائد التي يـدفعها المقترضـين تسـتقطع مسن أربـاحهم أو أصولهم الحقيقية، أو دخولهم، فإن زيادة الديون تؤدي إلى زيادة الجزء المستقطع من

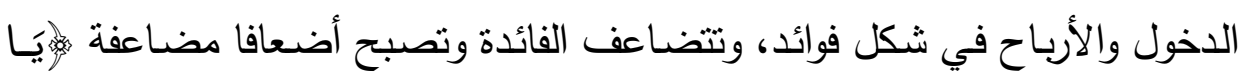

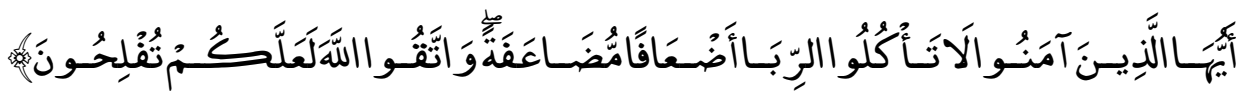
(آل عمران: · ب ا)، ومـع مرور الزمن يتن إعادة توزيع الثروة من القطاع الحقيقي المنتج إلى المؤسسات الربوية، وبتزايد الفوائد التي يجب على القطاع الحقيقي دفعها على الديون، يصل القطاع الحقيقي إلى مرحلة لا يستطيع فيها خدمة الدين، فنتشأ

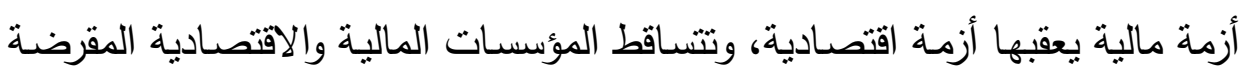

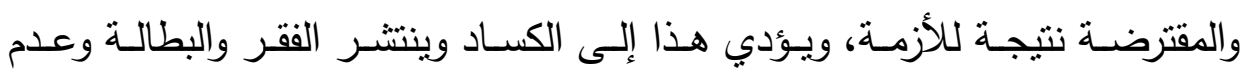

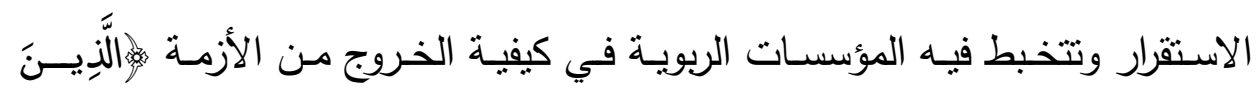

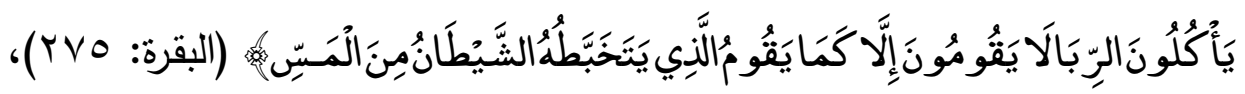
ويتم تصحيح الاختلال والخروج من الأزمـة بشطب الديون عن المؤسسات المدينة

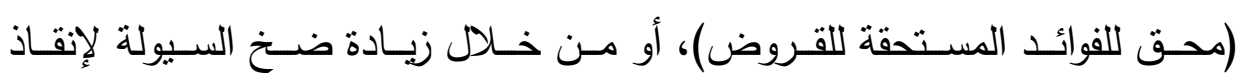
المؤسسات المفلسة، وهذا يؤدي إلى زيادة مستوى الأسعار والى التضخم الذي يؤدي

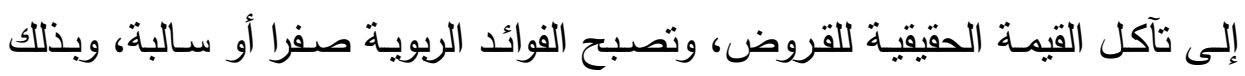

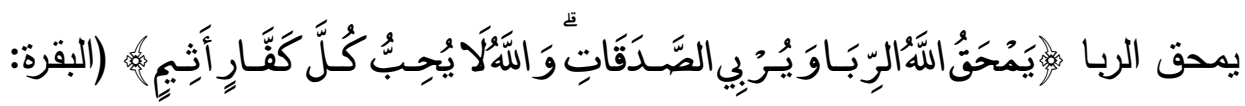
( ( Y T 


\section{الفائدة الحقيقية (عائد رأس المال)}

وتقرق النظرية الاقتصادية بين سعر الفائدة النقدي (ربا القروض)، وبين سعر

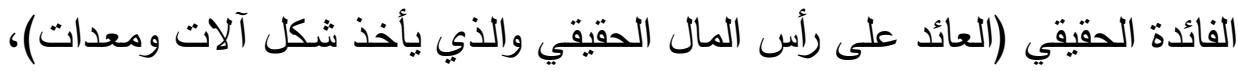

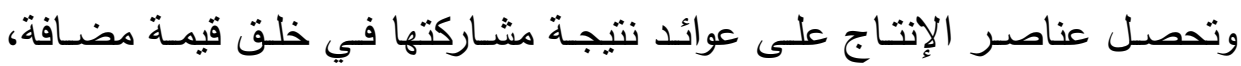
ويتحدد نصيب كل عنصر من القيمة المضافة حسب نظرية التوزيع، (التي تحكم

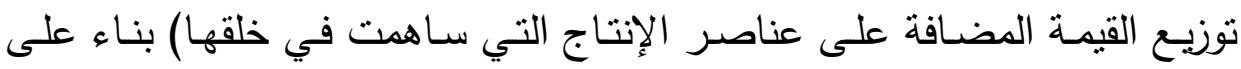

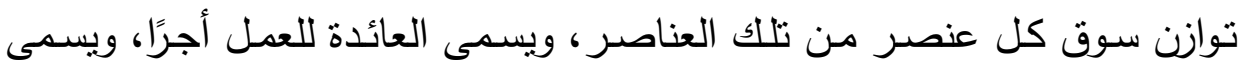

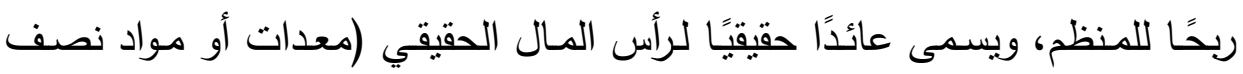

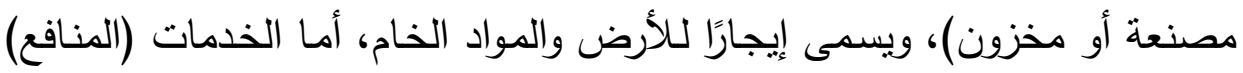

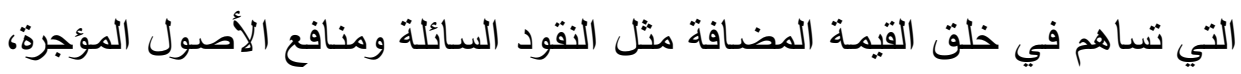
يسمى العائد الذي تحصل عليه إيجارًا، وفي اقتصاد نستخدم فيه النقود كوسيلة

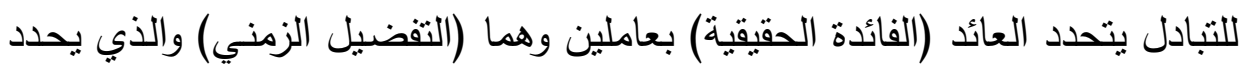

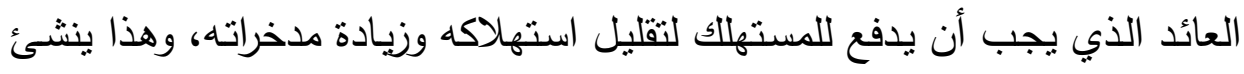

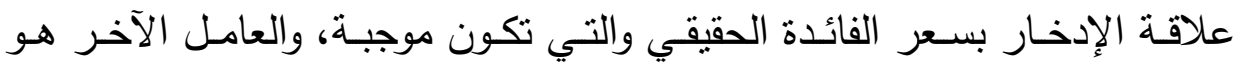

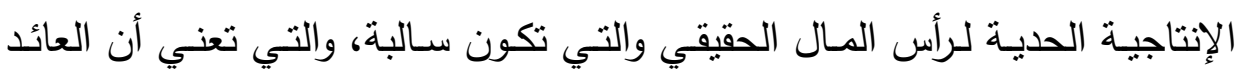

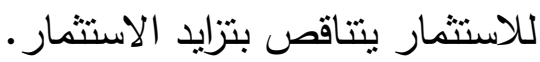
العائد الإسلامي على رأس المال وهو العائد الذي يحصل عليه رأس المال الحقيقي نتيجة مساهمته في العملية

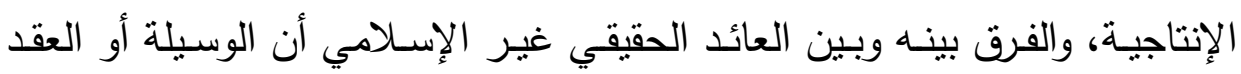

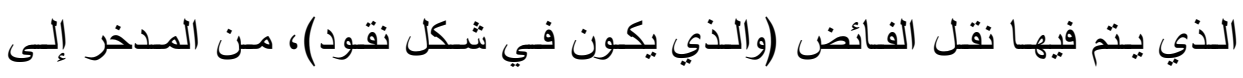

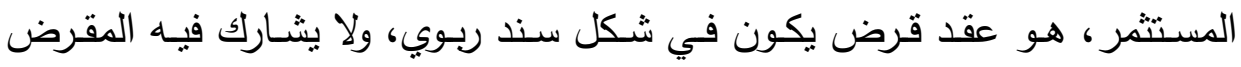

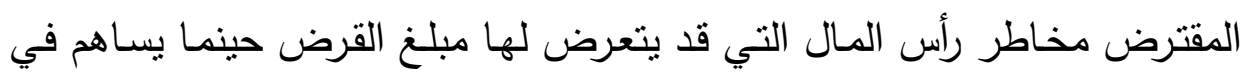
العملية الإنتاجية في النظام غير الإسلامي، بينما يكون في النظام الإسـامي، عقد 
مشاركة أو مضاربة لا يتم فيها تحديد العائد على الإدخار ولا ضمانه، أو عقد بيع

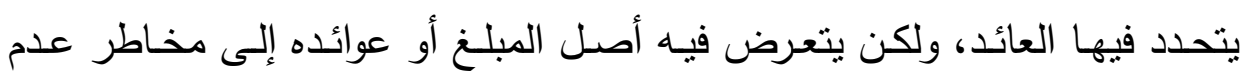
السـداد أو مخاطر العمليـة الاقتصـادية، وبذالك تتطبق قاعدة (الخراج بالضـمان)، وقاعدة (الغنم بـالغرم) على العقود الإسـلامية، ويحدد العائد الحقيقي الإسـلامي عاملين هما الإدخار والاستثمار .

وبسبب حب الإنسان إلى العاجلة عن الآجلة يجب أن يعوض بعائد حتى يؤجل

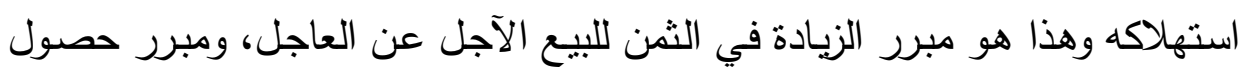
رأس المال المستثر بعقد المشاركة أو المضاربة على الربح (وهو عائد غير مضمون

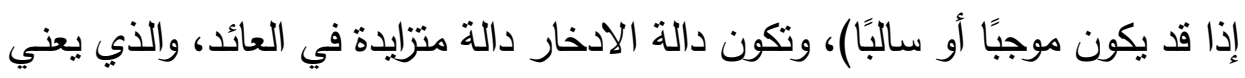
كلما توقع المدخر زيادة العائد، يزيد مدخراته، والطلب على هذه المدخرات يكون من قبل المستثمر ويتتاقص العائد المتوقع على الاستثمار بزيادة كميات الاستثمار نتيجة لتتاقص الإنتاجية الحديـة لرأس المـال أو لتتاقص الكفاءة الحديـة لرأس المال، كذلك الك الكيات الزيادة في الثمن الآجل يقلل من التوسع في الطلب على البيوع الآجلة، وبذلك تكون دالة العرض للمدخرات الإسـامية دالة متزايدة في العائد على الادخار ، ودالة الطلب على الاستثمار دالة منتاقصة في العائد.

\section{علاقة الفائدة النقدية بالمتفيرات الحقيقية}

إن الدراسـات الاقتصـادية تثبـت أن الفائدة ليس لهـا تـأثير على المتغيـرات الحقيقية، وإن كان لها تأثثير موجب فإنها مؤقت وأنـه يتلاشى بعد فترة، أن الفائدة النقدية عند كينز هي ظاهرة نقدية وليس حقيقية، بمعنى أنها نقد مقابل نقد وزيادة نتيجة الأجل، وهي بسبب التفضيل النقدي، وليس هناك أيسة نشاط حقيقي في هذه ونه

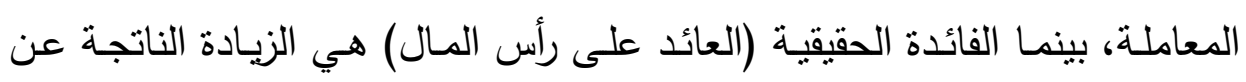
القيمة المضافة المصاحبة لعملية إنتاجية، والتي تحصل عليها عناصر الإنتاج بما فيها النقود، وأن أخذت (عناصر الإنتاج) في مرحلة التبادل شكل نقدي، ولكن هذا 
لا يلغي كون الادخار هو سلعة أو خدمة تأجل استهلاكها لتدخل في إنتاج سلعة

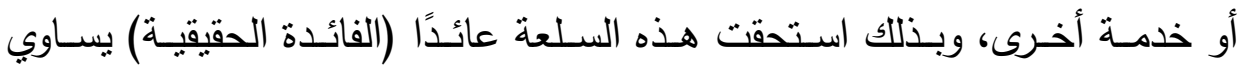

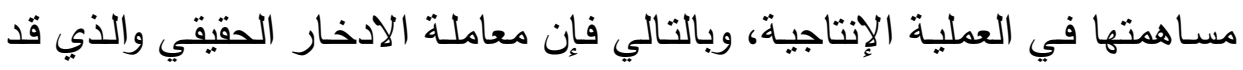

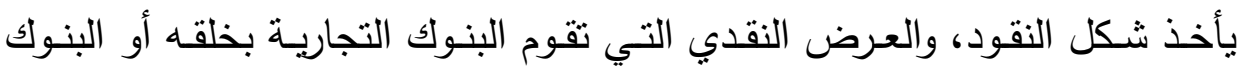

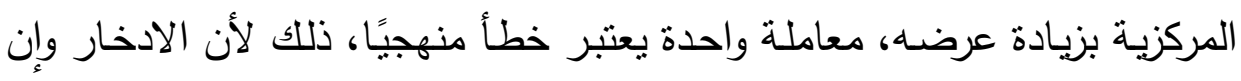

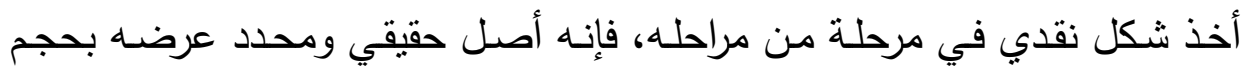

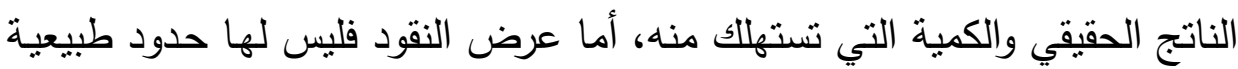

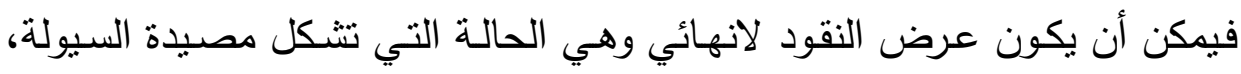

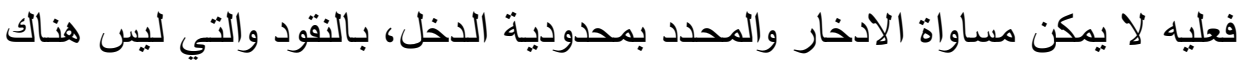
حدود طبيعيـة لعرضـها، لذلك دار جدل كبير حول حياديـة النقود بين الكنزيين

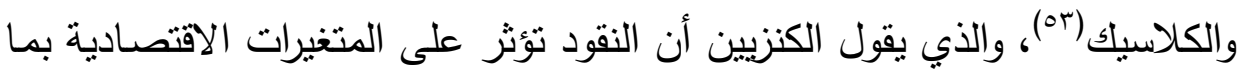
فيها سعر الفائدة بينما يعتبر الكلاسيك أن تأثير النقود على المتغيرات الاقتصادية

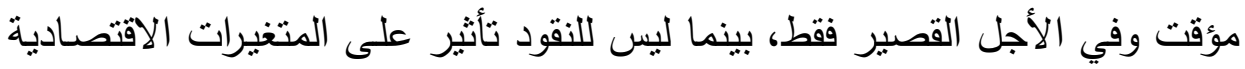

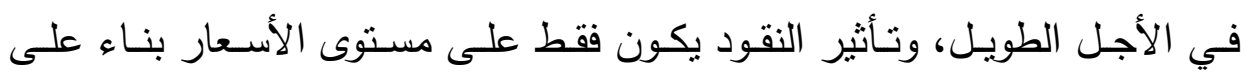

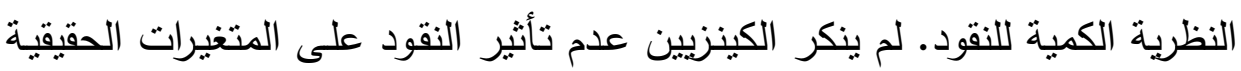

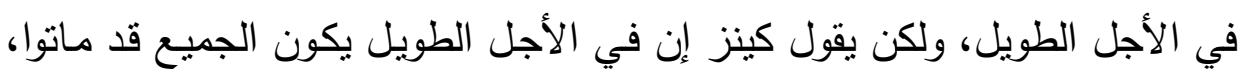

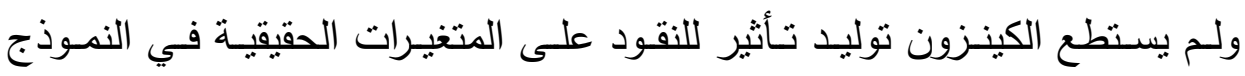
الكلاسيكي إلا بافتراض عدم المرونة في بعض المتنغيرات الاقتصادية مثل فئل الأجور

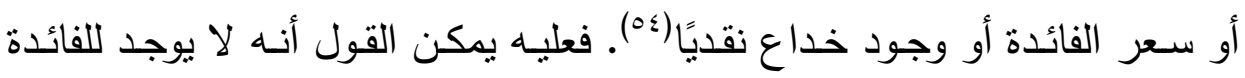

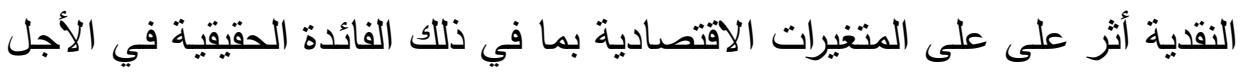
الطويل، وتأثيرها يتلاشى في الأجل الطويل.

Makinen, G.E. (1977) Money, The Price Level\& Interest Rate, Prentice-Hall New Jersy, (or) pp: $378-382$.

Makinen, G.E. (1977) Money, The Price Level\& Interest Rate, Prentice-Hall New Jersy, pp: (๑ 乏) 152-222. 
العلة الاقتصادية لتحريم ربا الايون

وتعرف العلـة الاقتصـادية بالوصف الاقتصـادي للمعاملـة والذي يؤدي إلى

التعرف المقصد مـن المعاملة والذي يتم فيها التوصـل لحكمها الثـرعي بقياسـها بحكم معاملات فقهية مسماة، كتطبيق أحكام النقود على النقد الورقي والائتماني لوجود علة قيامها بالوظائف الاقتصادية للنقود الذهبية والفضية، فيتحقق فيها علة تحريم الزيادة في القرض وهو تحقيق مصلحة العدل ورفع الظلم.

يمكن تحديد العلة من تحريم ربا الديون، من تعريف الربا والذي يعرف الربا بأنها: (زيادة أحد البدلين المتجانسين من غير أن يقابل هذه الزيـادة عوض)(00)، والتعربف الحنفي (فضل مخصوص مستحق لأحد المتعاقدين خال عما يقابله من عوض)(70)، فيكون علة الربا هي الزيادة المشروطة في البدلين المتجانسين من من غير أن يشـارك البدل في المخاطر أو يساهم في خلق قيمة مضـافة للطرف الذي يقوم بدفع العوض، فتكون زيادة بدون عوض. ويتوفر في هذه الزيادة الصفات

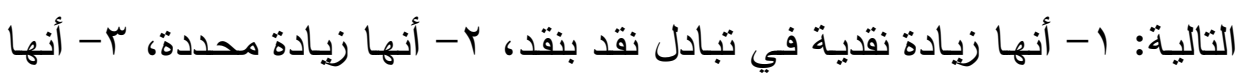
زيادة مضمونة، ع - أن أصل القرض مضمون، 0- أنها مرتبطة بالزمن.

والزيادة في القروض الربوية زيادة بدون عوض حتى لو استخدم النقد المقترض في النشاط الاقتصادي ونتج عنه قيمة مضافة، كما في المنشآت الاقتصادية التي تقترض للتوسع في الإنتاج، فإن القيمة المضـافة تكون من حق المقترض وليس للمقرض فيها حظ، لأن قرضــه كـان مضـموناً وتحمـل المقترض خطر هـلإك القرض، فـلا يجتمـع الخراج والأمان تبعًا للقاعدة الفقهية (الخراج بالضمان).

(00) عبدالرحمن الجزيري (1 •ـ (اهـ) كتاب الفقه على الدذاهب الأربعة، بيروت: دار الريان للتزاث، . $r \leqslant 0 / r$

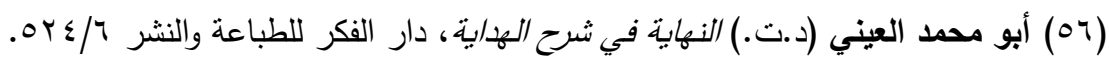


حكمة تحريم الريا الديون

يمكن استتاج الحكمة من تحريم الربا من نص آية تحريم الربا في قوله تعالى:

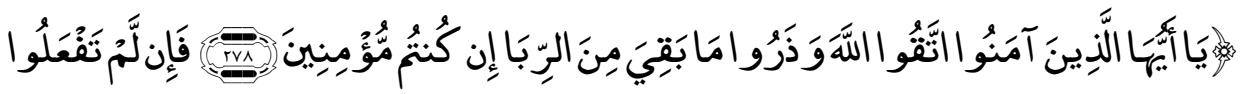

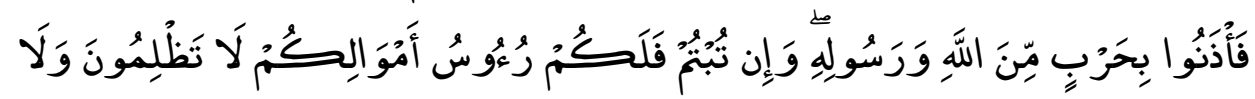

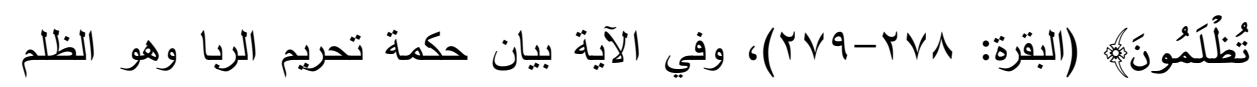

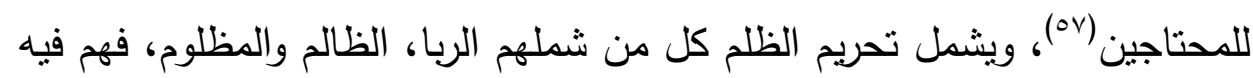

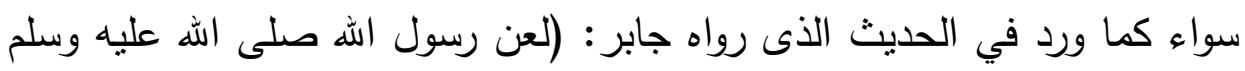

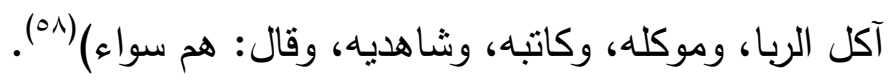

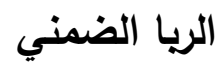

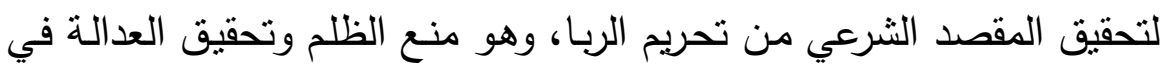

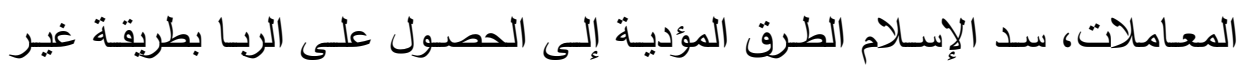

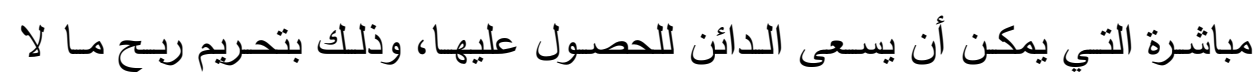

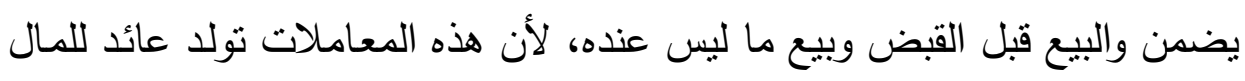
المستثر تتطبق عليه مواصفات الربا، كما سد الإسلام الطرق التي تؤدي إلى ظلى لـان

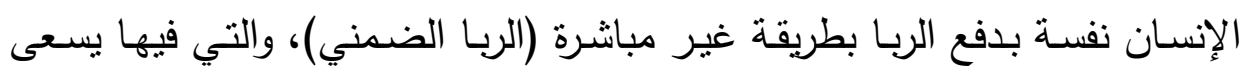

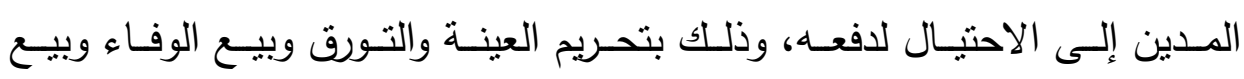

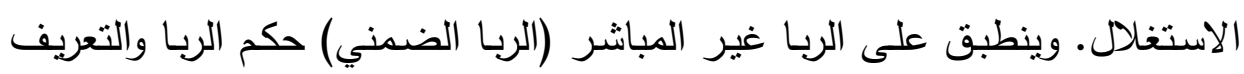

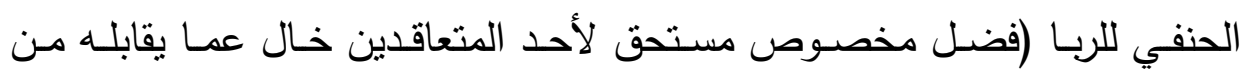

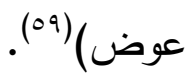

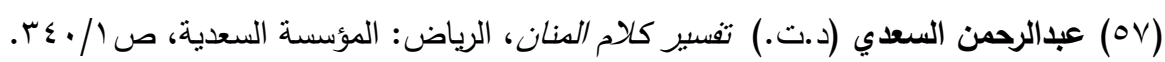

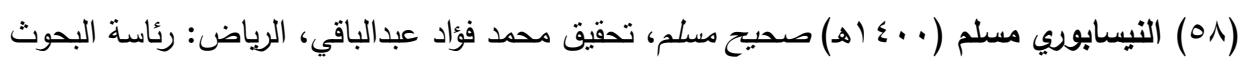

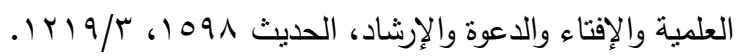

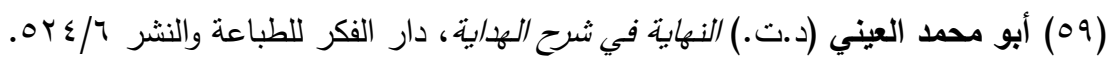


ثانيا: ريا البيوع

\section{التمويل في البيوع}

البيع في اللغنة هو مقابلة الثيئ بالثيئ أو تمليك المـال بالمال، أو إخراج

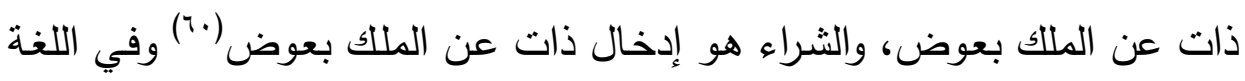

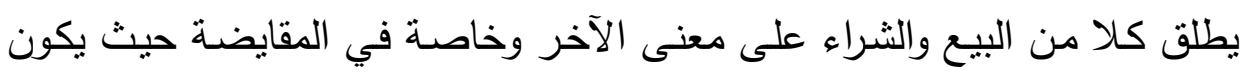

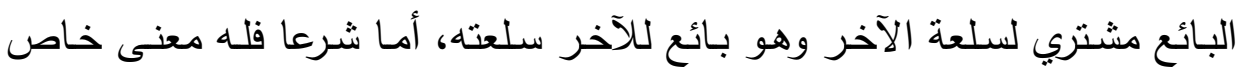

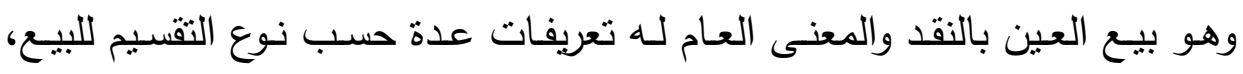
فبإعتبار تأجيل أحد البلالين وهو ما يعرف بالتمويل، فينقسم إلى أربع أقسام وهم:

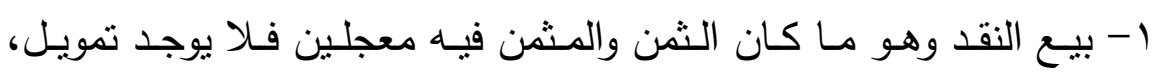

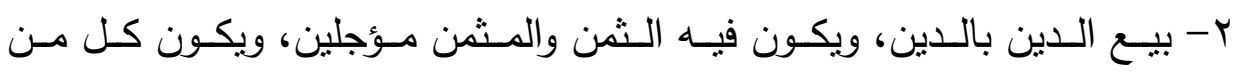

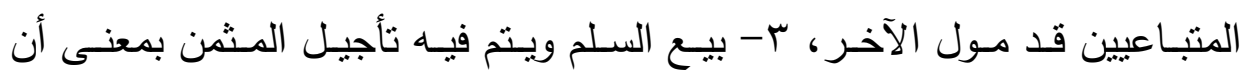

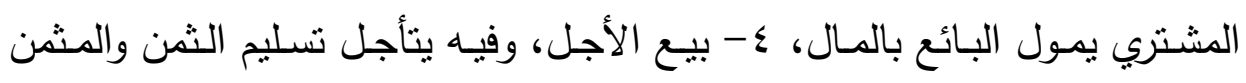

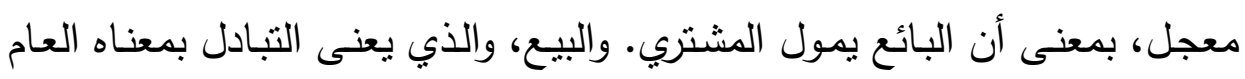

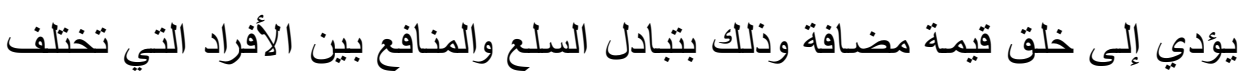

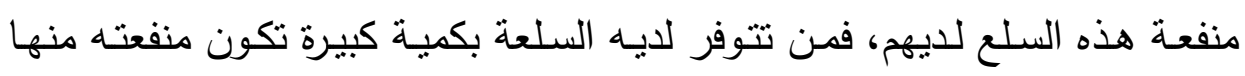

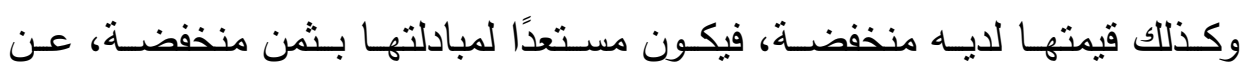

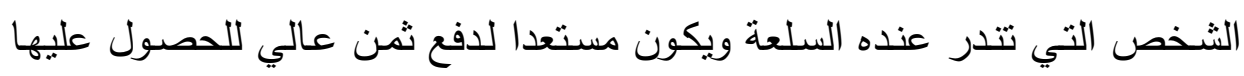

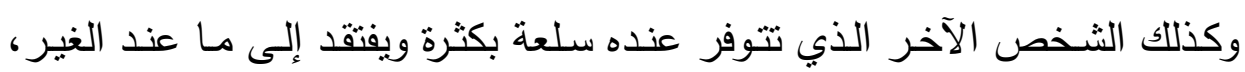

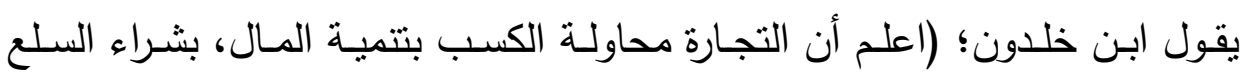

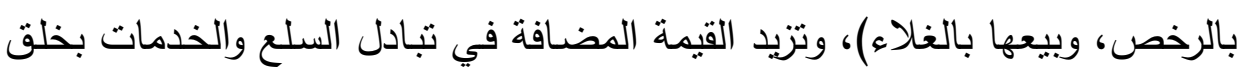

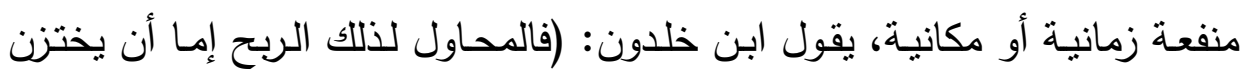
السلعة ويتحين بها حوالة الأسواق من الرخص إلى الغلاء فيعظم ربحه (وهذا يعني

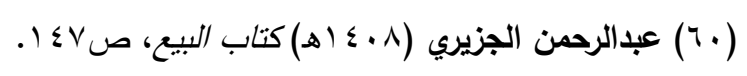


تخزين السلعة وقت وفرتها وبيعها وقت ندرتها وزيادة الطلب عليها)، أما أن بنقله من بلد آخر فيه السلعة أكثر من بلده التي اشتراها فيه، فيعظم ربحه) ويضيف سبب ثالث هو (بيعها بالغلاء على الآجال)(آ) وهنا الربح هو تكلفة تمويل شراء السلعة بالأجل، وعلى مستوى الاقتصـاد الكلي يؤدي التبادل إلى استخلال الموارد

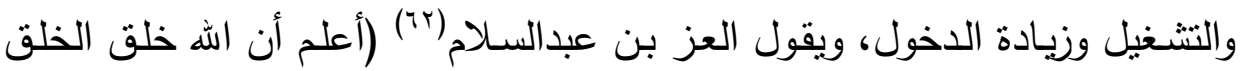
وأحوج بعضههم إلى بعض، لتقوم كل طائفة بمصسالح غيرهـا) ويجمل ابن تيميـة

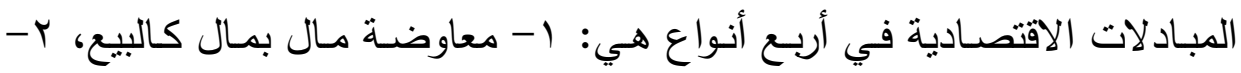

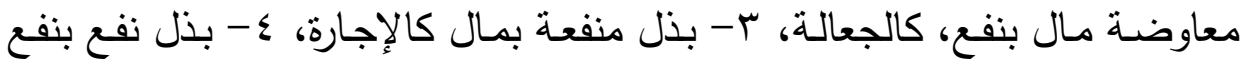

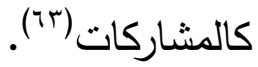

في الوقت الذي أحل الإسـلام التبادل في قوله تعـالى: (وأحل الله البيع) بكل أنواعه بما في ذلك البيع الذي يتضمن التمويل مثل بيع الأجل وبيع السلم، وأجاز في هذا البيع أن يكون للأجل حصـة من الثمن بسبب المنفعة الزمانية التي يحصل عليها المشترى من السلعة قبل تسديد الثمن، فالإمـام الثـافعي يقول: (الطعام إلى الأجل القربب أكثر قيمة من الطعام الذي إلى أجل)(ء)، ويقول ابن تيمية: (الأجل

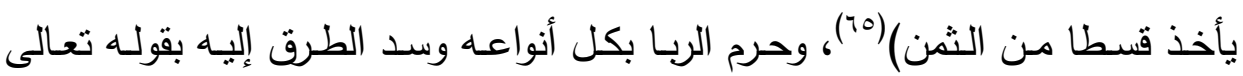
(وحرم الربا)، ونظرا لأن الربا هو تمويل ولكن محرم، والبيع الآجل هو أيضا تمويل لكنه جائز، فقد انصبت جهود الفقهاء في تحديد الحد الفاصل بين التمويل الجائز

(ا7) عبدالرحمن ابن خلدون (د.ت.) الكقدة، تحقيق على عبدالواحد وافي، القاهرة: دار نهضة مصر ، $9 r v / r$

(rT) العز بن عبدالسـلام (·191 (م) قواعد الأحكام في مصالح الأيام، تحقيق طه عبدالرؤوف سعد،

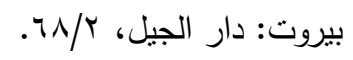

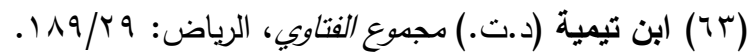

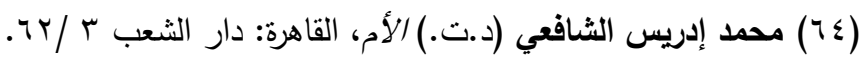

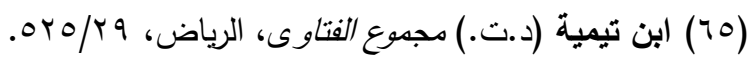


والتمويل المحرم في البيوع فكانت الأدبيات الفقهية الغزيرة والاختلافات حول ما يقع فيه الربا من البيوع وما ليس بربا من تلك البيوع.

ريا البيوع

ويقصد بربا البيوع زيادة أحد العوضين على الآخر في بيع الأموال الربوية(Tج)، ويكون (ربـا فضل) في بيـع متجانسين متفاضلين مبادلة فوريـة، وتكون الزيـادة في الـوزن أو الكيـل، ويسـىى (ربـا النسـاء) في مبادلـة متجانسـين (ذهـب بـذهب)، أو

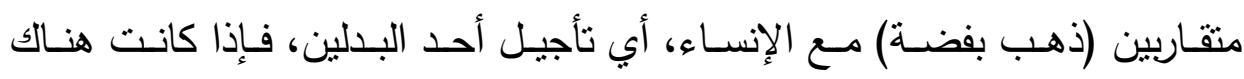
مفاضلة ونساء في مبادلة متجانسين، مثل . . 1 ذهب بـ ـ 1 ا ذهب آجل، كان ربا نسيئة وهو ربا القروض ويأخذ حكمة وإن سمي بيعا. وقد ورد في ربا البيوع أحاديث عدة ذكر منها السبكي في التكملـة اثتين وعشرون حديثا(TVآ، مـن أتمها وأجمعها حديث عبادة بن الصامت الوارد في الصحيحين، عن النبي صلى الله عليه وسلم أن قـال: (الذهب بالـذهب، والفضـة بالفضـة، والبـر بـالبر ، والثـعير بالثـعير، والتهـر

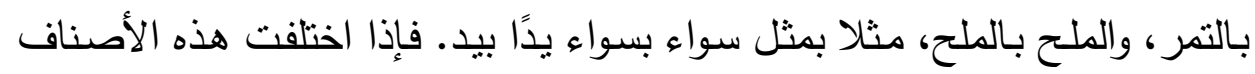

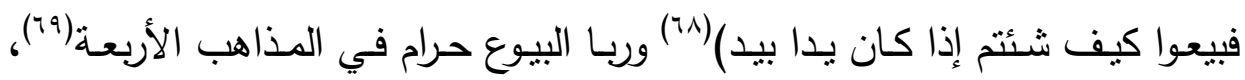

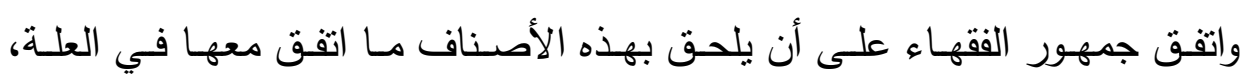
واعتبروا أن الحديث الخاص بالأصناف التي يجري فيها الربا هو من الخاص الذي

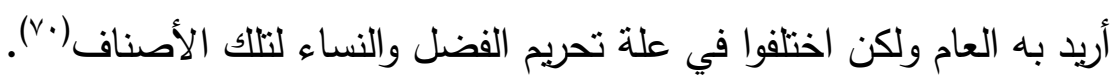

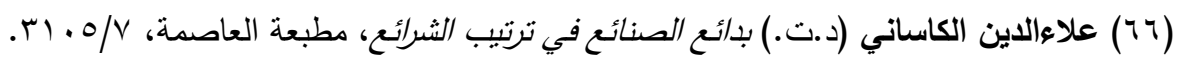

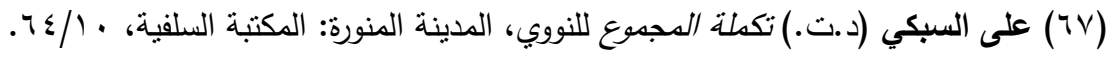

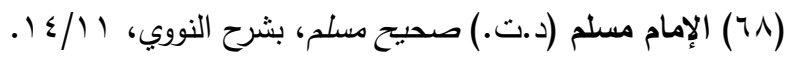

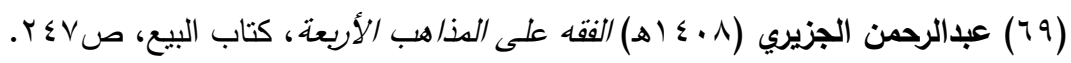

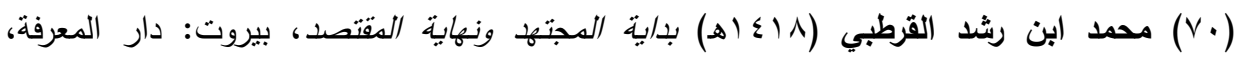




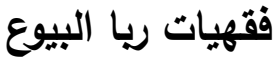

1- يمكن تصنيف الأموال الربوية الواردة في الحديث إلى فئتنين، ا- نقود

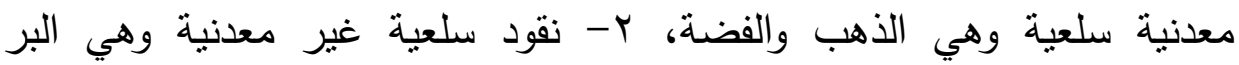
والثعير والتمر والملح.

ץ- يشـترط في تتبـادل النقود المعدنيـة بجنسـها، (ذهب بـذهب) أن تكـون

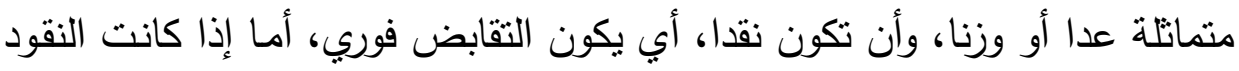
المعدنيـة متقاربـة (ذهب بفضـة) وليست متجانسـة، لا يشترط فيها التماثل ولكن النها يجب أن يكون فيها التقابض فقط.

r- يشترط في تبادل النقود السلعية بجنسها (البر بالبر والثشعير بالثتعير،

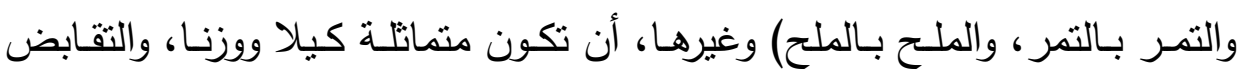

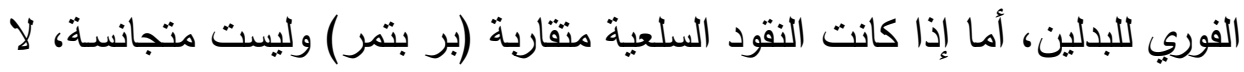

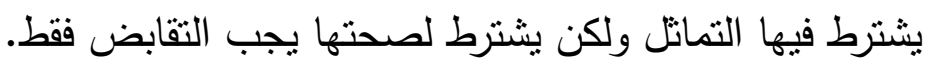
ع - في تبادل النقد المعدني بالسلع التي تستخدم كنقود (النقود السلعية)، لا يشترط فيها التمانل أو الثقابض.

\section{الفقهيات الاقتصادية لريا البيوع}

1- إن جميع الأصناف السته الواردة في الحديث يمكن أن تصنف بأنها نقود سلعية لأنها تتوفر فيها معظم المواصفات المرغوبة في السلعة حتى تستخدم كنقود،

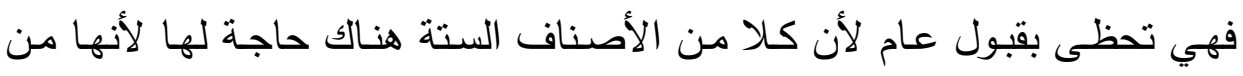

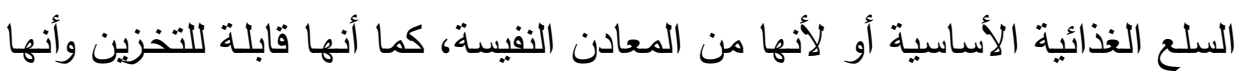

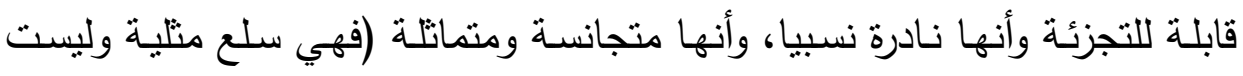
قيمية)، كما أنها مارست وظائف النقود، ويمكن تقسيم النقود السلعية الواردة في 
الحديث إلى سلّع معدنية، وهي الذهب والفضـة، وسلع غذائية، وهي البر والثـعير والتمر والملح، وتختلف درجة النقدية (مدى توفر المواصفات النقدية) بين النوعين من النقود، فتتوفر بدرجة أكبر في النقود المعدنية عن النقود السلعية الغذائية. r- يلحق بالأصناف السته المذكورة في الحديث، كل سلعة يمكن أن تتوفر فيها الصفات التي يجعلها نقود وأهم تلك المواصفات أن تكون سلعة مثلية، وذلك حتي يمكن أن تمـارس وظـائف النقود، وهي أن تكون وحدة لقيـاس القيم وسيط للتبادل، وهذا يعنى ألا تلحق بالأصناف الستة السلع القيمية والتي تختلف وحداتها أو تتغير قيمتها بالنمو أو التلف مثل الحيوان والفاكهة والخضار . r- تستطيع الأصناف السته ممارسـة دورين في الاقتصاد، فهي قد تستخدم كسلعة استهاكية يشتربها المشتري لمنفعة استهالاكها، كما في الأصناف الأربعة أو للتجمل كما في الذهب والفضة، فيكون لها قيمة استهلاكية، وقد تستخدم وسيط للتبادل كنقود فيكون لها قيمة نقدية. ع- وضـع الحديث الثريف ضوابط واشتراطات في استخدام هذه الأصناف الستـه، تؤودي إلى سـ كل الطـرق إلى الربـا وتؤدي إلى تحقيق العدل في حالـة اسـتخدامها كنقود، وسـمح لهـا الحصـول على قيمتهـا العادلـة السـوقية في حالـة استخدامها كسلعة اقتصادية.

0- يعرف الربا بأنه: الزيادة التي تثقرر في الذمة في الدين الناشئ عن سلف أو بيع نظير الأجل: زيادة أحد العوضين على الآخر في بيع الأموال الربوبة(V)( ففي مبادلة (بيع) الذهب بالذهب أو الشعير بالثعير مثلا بمثل ويدا بيد لا يوجد

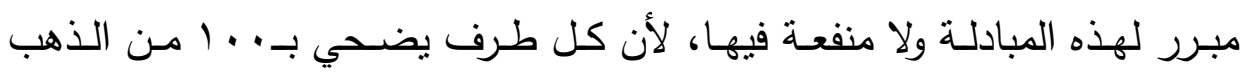


ويحصل على · . 1 حالـة، وتحصـل المنفعـة إذا تم التبـادل بـ . . بـ 1 1 حالـة ويكون في ذلك سفه وعدم رشد اقتصادي من المشتري، وظلم من البائع لأنه أخذ ال • 1 بدون مقابل، وهذا هو ربا الفضل، وحيث إن الأصناف موضع التبادل سلعة منليـة ومنفعتها متجانسـة، أهدر الثـارع فرق الجودة أو الصنعة حتى لا تسـتخدم كوسيلة للتحايل على ربـا الفضل، فيكون الربـا، أو (الفضـل الخـالي مـن العوض المشروط في البيع)(VY)، لذلك كان شرط التماثل في الحديث لتحقيق العدالة في التبادل. وكذلك لو تم تبادل . 1 بـ . . 1 ولكن مؤجلة لأحد المتبادلين، فيكون من قبض الـ . . 1 مؤجلة قد انتفع بها أكثر ممن سوف يستلمها مؤجلة، فلا تكون المئة الناجزة تساوي المئة المؤجلة، ويقول الكاسـاني: (لا مساواة بين النقد والنسيئة، لأن العين خير من الدين، والمعجل أكثر قيمـة مـن المؤجل)(rr)، فيكون ربـا النسـاء، ويتحقق عدم التسـاوي في المنفعـة بين البدلين، وهذا ينـافي مـع مبدأ العدالـة في التبـادل، لذلك كان شـرط التقابض والتماثل في التبادل في حالـة التجانس وذلك لتجنب الربا ولتحقيق العدالة في تبادل السلع التي قد تستخدم كنقود. ج- في حالة تبـادل الأصناف المتقاربـة ولكن غير المتجانسـة (السـلع النقديـة المتقاربة) ولكن من نفس الفئة (نقود معدنية أو نقود سلعية) مثل الذهب بالفضـة أو الثعير بالتمر ، في هذه الحالة منافع كل منها مختلف عن الآخر فالذهب استعمالاته

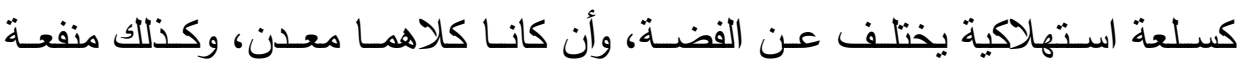
واستعمالات الثعير يختلف عن التمر وأن كانا كلاهما طعام لذلك، قد يتم تبادلهما لأغراض استهلاكية وليست نقدية، لذلك لا يشترط في تبادلها التماثل وزنا أو عدا، ولكن يثترط في هذه الحالة التقابض، وقد اثترط هذا الثرط حتى يكون الغرض من

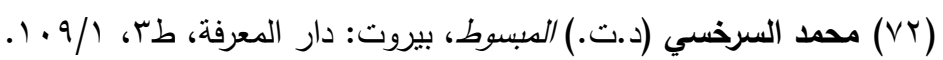

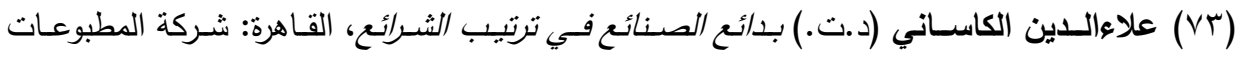
العلمية، NV/0 
البيع هو منفعة السلعة المشتراة، لا يكون عقد ظاهره البيع ولكن يقصد منه التمويل، وذلك باقتراض ذهب وهو نقد معدني ورده فضـة لأجل وهو نقد معدني، أو اقتراض شعير ورده تمرًا مؤجلاً وكلاهما نقود سلعية، فيكون نقد عاجل بنقد آجل أكثر، عدًا أو وزنًا، فيتحقق بذلك وصف ربا النسيئة، وهو زيادة أحد العوضين على الآخر في بيع الأموال الربوية، لذلك وجب التقابض في هذا التبادل حتى لا يكون ذريعة إلى الى

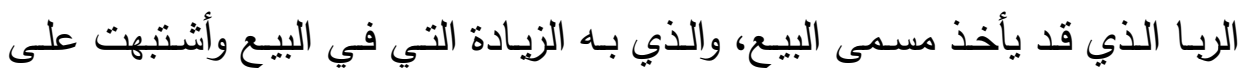

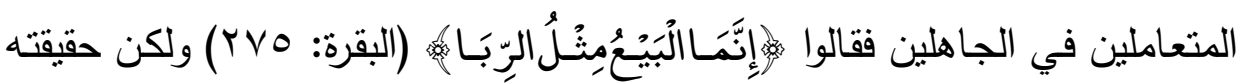

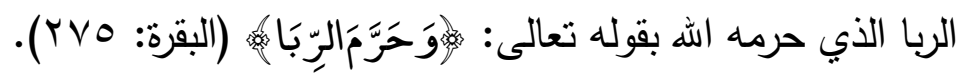

- في حالة تبـادل السـلع التي قد تكون نقديـة بغير نقديـة، أو تكون نقديـة بسلع نقديـة من غير الفئة، مثل ذهب بفاكهة أو ذهب بشـير ، فيغلب على هذا التبادل أن يكون بغرض تحقيق الفائدة الاستهلاكية من تلك المبادلة، وهو الغرض

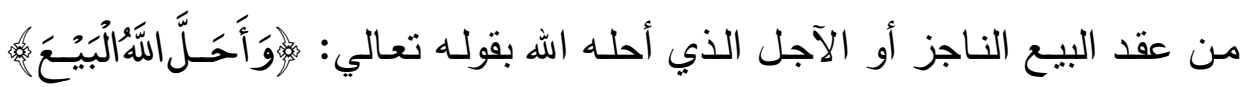
(البقرة: rV0)، لذلك لا يشترط في هذا التبادل التماثل أو التقابض، إذ ينت تبادل هذه السلع حسب قيمتها الاستعمالية العادلة التي يحددها السوق. ^- في تبرير اشتراط التقابض في الصرف (بيع الذهب بالفضـة، أو تبادل

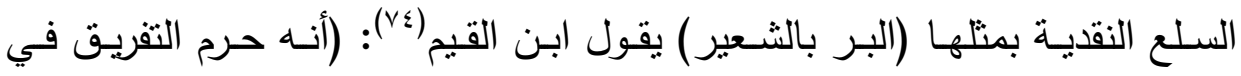
الصرف وبيع الربوي بمثلـه قبل القبض؛ لئلا يتخذ ذربعة إلى التأجيل وهو أصل بـل الربا) وفي تبرير شرط التماثل في تبادل الجنس الواحد بمثله (الذهب بالذهب)، يقول ابن القيم (ثم أوجب عليهم التماتل، وأن لا يزيد أحد العوضين على الآخر إذا كانا من جنس واحد حتى لا يباع مد بمدين رديئين وإن كانا يساويانه، سد لزريعة 
ربـا النسـاء والذي هو حقيقيـة الربـا، وأنـه إذا منعهم مـن الزبـادة مـع الحلول حيث تكون الزيادة مقابل جودة أو صفة أو سكة أو نحوهما، منعهم منها (الزيادة) حيث لا مقابل لها إلا الأجل أولى؛ فهذه هي حكمة تحريم ربا الفضل).

9- يمكن تعليل الربا في الأصناف الستة في الحديث بأنها من النقود السلعية لانطباق مواصفات النقود السلعية عليها، حيث الذهب والفضـة سلع معدنية، والبر والثـعير والتمر والملح سلع استهلاكية، هذا يؤدي إلى ترجيح رأي ابن القيم بأن قصد الثارع في تحريم ربا الفضل في هذه السلّع، أو الحكمـة من التحريم هو سد لذربعة ربا النسيئة، وقد استدل في ذلك من حديث تحريم ربا الفضل: (فاني أخاف عليكم الرما)، والرما هو الربا، ويقول: (فتحريم الربا نوعان: نوع حرم لما فيه دن المفسدة وهو ربا النسيئة، ونوع حرم تحريم وسائل وسد للذرايع (وهو ربا البيوع) لأنه يؤدي إلى مفسدة ربا النسيئة. • 1- لو اعتبرت الأصناف الستة هو نقود سلعية، يمكن تفسير ربا البيوع (الفضل والنساء)، بأنه يؤول إلى ربا النسيئة حينما ينتفي التقابض والتماثل في بيع السلـع المتجانسـة من النقود السلعية، وربا السنة (ربـا البيوع) جاء لسد أبواب الربا باء التي قد تستخدم عقد البيع للوصول إليه، وهذا يمكن فقط في النقود السلعية، ولكن حينما تطورت النقود واستخدمت النقود الائتمانية انتفت المقدرة على استخدام عقد البيع للنقود للوصول إلى ربا القروض أو ربا النسيئة، حيث إنه لا يمكن عقلا بيع العملة الورقية بجنسها إلا متفاضلة ومؤجلة تسليم العوض، فـ ـ. إيـال لا يمكن

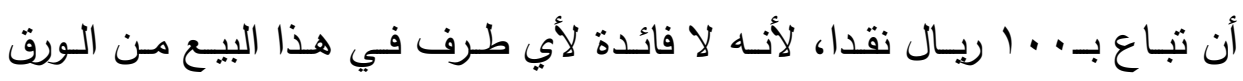
المتبادل، ولا يقبل طرف أن يدفع • 1 ا ريال مقابل · . 1 ريال نقدا لأن فيه غبن له، ولكن يدفعها إذا كانت مؤجلة لأجل، ولكن هذا يكون ربا نسيئة، وهذا تقسير الحديث الشريف الذي رواه أسامة بن زيد مرفوعًا إلى النبي صلى الله عليه وسلم: 
إنما الربا في النسيئة، حيث يفضي ربا الفضل إلى ربا النسيئة، وقد ذهب بعض العلماء(Vo) في تفسير الحديث أن (لا ربا) يقصد بـه الربـا الأغلظ الثديد التحريم وهذا لا ينفي وجود تحريم البيوع الوارد في حديث عبادة بن الصامت.

\section{التفسير الاقتصادي لعلة ربا الفضل عند الفقهاء}

تحريم ربـا الفضـل يكـون بقصـد تحقيق العدالـة في التبـادل بين العوضـين، ويقول ابن رشد (كان معقول المعنى في الربا هو ألا يغبن بعض الناس بعضـا،

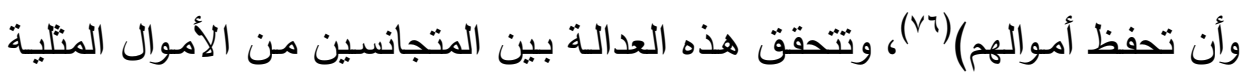
بتساوي العوضين كيلا أو وزنًا، لأن ذلك يحقق التساوي في قيمتهما، ولكن قد لا يتحقق في تبادل منلين غير متجانسين مثل بر بشعير إلا بالتفاضل، وينطبق ذلك في تبادل منلي بقيمي، كما أن التفاضل قد يحقق العدالة في تبادل قيمي بقيمي مثلـه مثنل تبـادل الثـاة بالثـاتين والسـيارة بالسـيارتين. وفي تفسـير عدم وجـوب التسـاوي في الســع القيميـة، بـل العدل يكون في عدم التسـاوي، يقول ابـن رشـد: (يظهر من الثرع أن المقصود بتحريم الربا إنما هو لمكان الغبن الكثير فيه، وأن

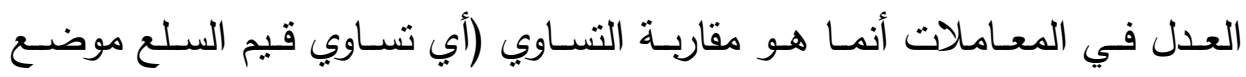
التبادل)، ولمـا عسر التسـاوي في الأشياء المختلفة الذوات (يقصد القيميـة) جعل الدينار والدرهم لتقويمها (يعني قياس قيمها)، ولما كانت الأشياء المختلفة الذوات (الغير موزونة أو غير مكيلة) العدل فيها وأنما في وجود النسبة، أعنى: أن تكون نسبة أحد الثيئين إلى جنسه قيمة الثـئ الآخر إلى جنسـ) (فيكون الفرس يساوي عشرة أثواب) (فإن اختلاف هذه المبيعات في العدد واجبة في المعاملة العادلة)،

(V0) محمد صلاح الصاوي (• (؟ (هـ) مشكلة الاستثمار في البنوك الإسلامية، المنصورة: دار الوفاء،

$$
\text { ص ص م }
$$

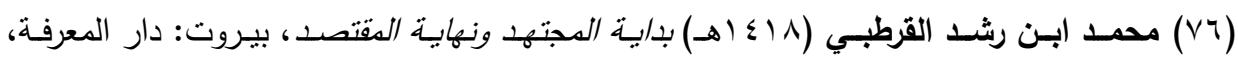


وفي تبرير وجوب المساوة في السلع المثلية المكيلة والموزونة يقول ابن رشد: (أمـا الأشياء المكيلة والموزونـة، فلما كانت ليس تختلف كل الاختلاف، وكانت منافعها متقاربة ولم تكن حاجة ضرورية لمن عنده منها صنف أن يستبدله بذلك الصنف بعينه إلا على وجه السرف كان العدل في هذا إنما في وجود التساوي في الكيل أو الوزن) ويذكر علتان في منع التفاضل في الوزن أو الكيل هما وجود العدل ومنع السرف، (أمسا الدينار والدرهم فعلة المنع فيها أظهر إذ كانت هذه ليست المقصود

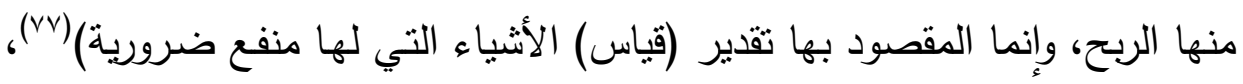
أي تمارس وظيفة قياس القيم.

قد اتفق الفقهاء على مقصد تحريم الربا إلا أنهم اختلفوا في تفسير العلة في تحريمسه، ولكن التقسير الاقتصـادي للعلل المختلفـة التي اختلف عليهـا المـاهب الفقهية يؤدي إلى إزالة هذا الاختلاف والى اتفاق هذه المذاهب على علة تحريم ربا الفضل وربا النساء.

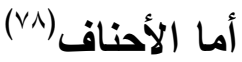

ذهبوا إلى أن علة ربا الفضل هي القدر مع الجنس، ويقصد بالقدر الكيل أو

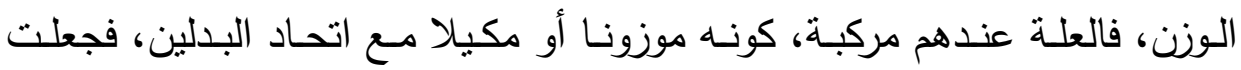
المماثلة شرطا في بيع المتجانس، والممانلة تكون في الصورة وذلك بتساوي القدر في البدلين بالوزن أو الكيل، فكيلوا البر يساوي كيلوا البر في مبادلة البر بالبر، وتكون المماتلـة في المعنى والتي تكون باتحساد الجنسيين ذلك أن المجانسـة في الأموال يؤدي إلى مسـاواة أو مقاربـة في المالية، فمنفعـة كيلو البر تساوي منفعـة

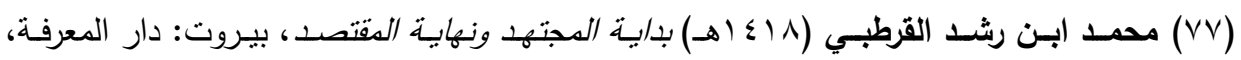
$.1 \wedge \varepsilon / r$

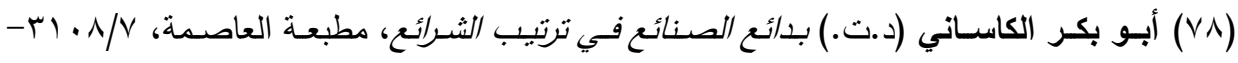


كيلو البر المتبادل، وفي حالة اتلاف كيلو بر يلزم المتلف كيلو بر • وأن أية زيادة عن التمانل تكون فضل مال خالي من العوض.

أن الكيل أو الوزن في السلـع المنبادلة يؤدي إلى ضبط مقاديرها وهذا شرط لأي سلعة حتى يمكن استخدمها كنقد في تبادل السلع حيث لا نشترى لذاتها وأنما لاستخدمها كنقد في شراء سلعة أخرى، وحينما تكون السلع المتبادلة متجانسـة (بر ببر) تكون ماليتها متنساوية، فعلية أية زيادة في تبادل الكميتين يكون فضل مال خـالي من العوض، وهذا ينطبق على كل النقود السـلعية، ولكن لـو انعدم أحد الشرطين أو كلاهما فلا يجري في السلع المتبادلة ربا الفضل، فالحيوان لا يمكن ضـبط قدره فيجـوز الفـرس بـالأفراس والنجيبـة بالإبـل، وكذللك في حالـة انعـدام

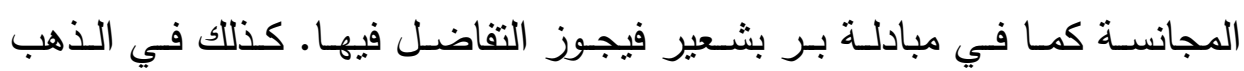

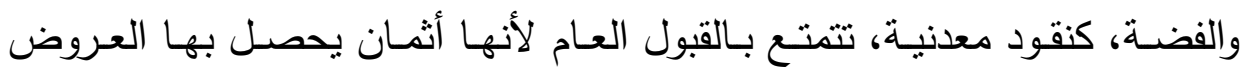
والثهوات، وتخلى بها الذم، كما أنه يجري فيها التقدير بالوزن أو العد، فالتفاضل لهانل في الجنس الواحد فضل مال خالي من العوض.

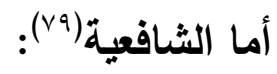

فقسمت ما يجري في الفضل إلى مطعومات وأثمان، أما المطعومات، فعلته الطعم مع التقدير في الجنس بالكيل أو الوزن، وكان تعليل تخصيص المطعومات في جريان ربالفضل هو كون الطعام تتعلق فيه النفوس، أما الأثمان وهي الذهب والفضــة فعلتها الثمنيـة، ذلك لأنسه يتوصـل بهـا إلى حصـول العروض والتي بها حصول المقاصد الأصلية من بقاء النفس.

(V9) المقسسي ابن قدامة (د.ت.) الدغني على مختصر الsقنع، بيروت: دار الكتاب العربي، Y Y Y. 
إن المطعومات تعتبر من السلّع الأساسية وبسبب حاجة الجميع إليها، فهي تحظى بقبول عام وهذه أحد المواصفات الأساسية لأي نقود سلعية، ويشترط فيها التقدير وهو لضبط التعامل حين تستخدم كوسيط للتبادل فإذا كانت هذه متجانسـة فيجب التماثل في تبادل الجنس بجنسـه فيكون تبـادل نقود سلعية بجنسها، وعدم التماتلل يؤدي إلى فضل مال خالي من العوض وهو ربا الفضل، وعند المذهب لو انعدم التقدير بالجنس فلا ربا.

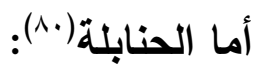
يجري ربا الفضل عندهم فيما اجتمع فيه الكيل أو الوزن (التقدير)، والطعم من الجنس الواحد في المطعومات والثمنية في الأثمان، والتبرير لهذه العلة كما في بقية المذاهب لأن الطعام يحتاج إليه الجميع فهو نقود سلعية تحظى بقبول عام، والتقدير يجعلها وسيط جيد للتبادل، وكذلك الذهب والفضـة والذي يحظى بقبول عام لندرته ولثمنيته، لذلك التفاضل في هذه الأنواع بجنسها يثترط فيه التماثل، وعدم التماثل يؤدي إلى حصول أحد المتبادلين على فضل مال بدون عوض.

المالكية

فإن علة ربا الفضل عند المالكية في المطعومات، هو الصنف الواحد والاقتيات والادخار ، وقد قيل الصنف الواحد المدخر وإن لم يكن مقتاتا، ومن شرط الادخار عندهم أن يكون في الأكثر، وحجتهم في ذللك أنـه لـو كان المقصـود من الأربعـة الأصناف الطعم لاكتفى بواحد من المطعومات، وقد ذكر منها عدد للتتبيه على ما في معنى كل صنف، كالحبوب المدخرة في البر والثـعير، والحـاوة المدخرة في التمـر، والتوابل في الملـح، ويجمعها جميعا صفة الاقتيـات والادخـار ، والحكمة في

(^) المقدسي ابن قدامة (د.ت.) الدغني على مختصر الدقنع، بيروت: دار الكتاب العربي ع/rol- 
تحريم ربا الفضل في المطعومات المدخرة هي ألا يظلم بغبن بعض الناس بعضنًا،

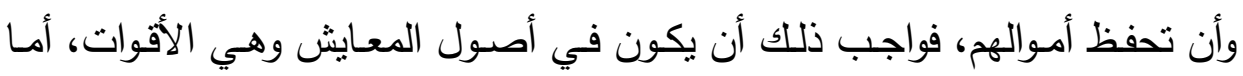
العلة في الذهب والفضة فهي الثنية، إذا أنهما رؤساء للأثمان وقيما للمتلفات. يمكن القول أن المالكيـة ركزت على الأقوات لأنها أصسول المعـيش، لذلك تحظى بالقبول العام ويمكن أن تمارس وظيفة التوسط في التبادل، كما اشترطوا أن تكـون الأقـوات مـدخرة حتـى يمكـن أن تمـارس وظيفـة مخـزن للقيم وهـي مـن المواصفات المرغوبة في السلع كي تكون نقود سلعية، أما في الذهب والفضـة فهي بسبب ثمنيتها، تحظى بقبول عام وبها أكثر الثروط المرغوبـة في النقود السلعية لذلك يشترط في تبادل الذهب بالذهب التماثل والتقابض ولكن في مبادلة الذهب بالفضة التقابض فقط.

\section{التفسير الاقتصادي لعلة ربا النساء}

إن مقصد تحريم ربـا النسـاء هو تحقيق العدالـة في التبادل بين العوضـين، وتتحقق هذه العدالة بين المتجانسين من الأموال المثلية بالتقابض الفوري للبدلين، لأن ذلك يحقق التساوي في قيمتهما، ولكن يجوز التأجيل في مبادلة أموال مثلية غير متجانسـة وليست من نفس الفئة مثل ذهب ببر ، وكذلك مبادلة أموال مثلية ونة بأموال قيمية مثل ذهب بشاة، لأن التفاضل بينهما يسمح بتحقيق العدالة في القيمة بين المثمن (البر) والثمن الآجل وهو الذهب، ولكن بناء على حديث سمرة مرفوعا

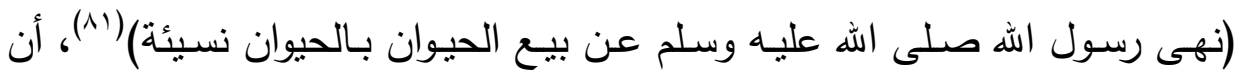
النسـاء غير جائز في الأموال القيمية والتي يمكن أن تتمو أو تتغير قيمتها مـع

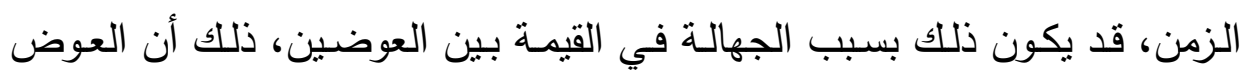


المؤجل قد يتغير مع الزمن بالنمو أو التلف فلا تتحقق العدالة في التبادل. ولكن ما هو تفسير الاقتصاديون لعلة تحريم ربا النساء؟

إن التفسير الاقتصادي لعلة ربا النساء هو الزمن في السلع النقدية سواء معدنية أو استهـلاكية، ذلك أن الزمن يـؤثز في قيمـة النقود لأن النقد الحـال أكثر منفعـة، وبالتالي أكثر قيمـة مـن النقد المؤجـل، وفي ذلك يقول الإمـام الشـافعي رحمـه الله: (مائة صاع أقرب أجلا من مائة صاع أبعد أجلا منها، أكثر في القيمة)(r^)، وقال كاسـاني: (لا مسـاواة بين النقد والنسيئة، لأن العين خير من الدين، والمعجل أكثر

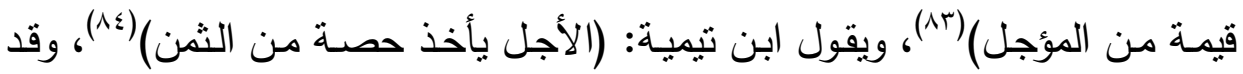
أهدر الإسلام أية زيادة في تبادل النقود واعتبرها ربا محرما، ولكن أجاز الزبادة في

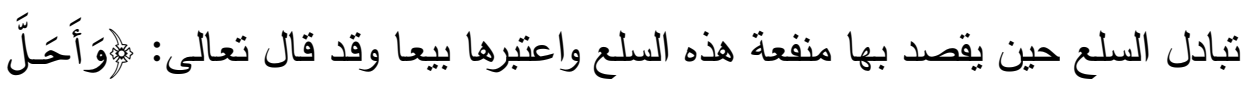

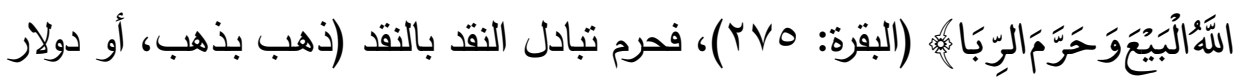
بدولار، بر بير، تمر بتمر)، إلا يدا بيد ومثل بمنل، فإذا كان مثل بمثل ولم يكن يدا بيد أدى هذا إلى ربا النساء وهي الفائدة التي يستقيد بها المعجل عن المؤجل وهي محرمة، وفي تبادل نقود سلعية متشابة ولكن ليست متجانسة مثل ذهب بفضـة، وبر

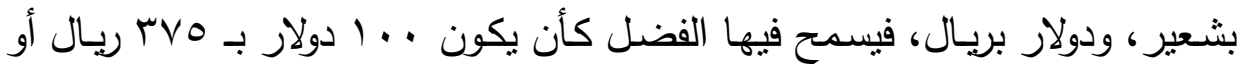
صاع بر بصاعين شعير ، ولكن اشترط أن تكون بدا بيد، ذلك سدا لذربعة الربا، ذلك

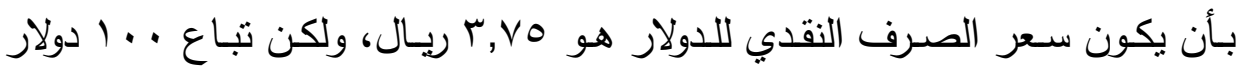

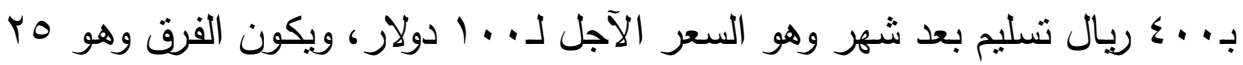
ربـال هو الفائدة للتأجيل ولكن أدمجت في سـر بيع الدولار الآجل، وينطبق ذلك

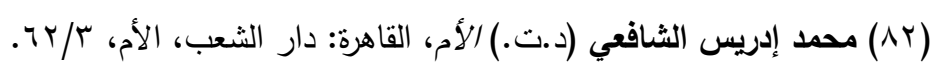

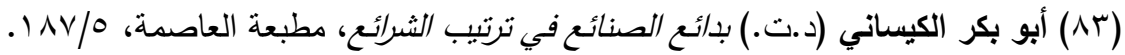

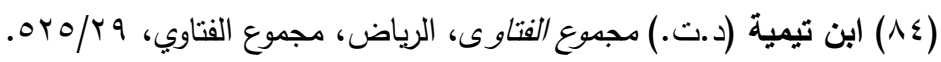


على كل النقود السلعية والنقود الأثتمانية. وبذللك تكون علة ربـا النسـاء هي النقدية والتجانس أو النتـابه في النقود سواء كانت نقود سلعية أو ائتمانية، ويقصد بالنقود السلعية، السـلع التي تستخدم كنقد ولها المواصفات المرغوبـة في النقد لكي يمارس الكس وظـائف النقود وأهمها أن يكون وسـيط للتبـادل مثنل الذهب والفضـة والبلاتونيوم، والبلاتين، والقهح والأرز والثـوفان، والتمر والزبيب والعسل، وكل ما يصطلح عليه

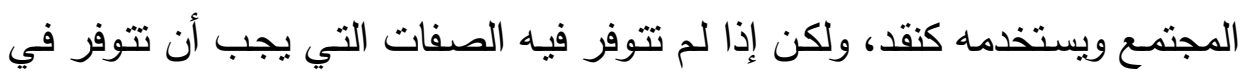

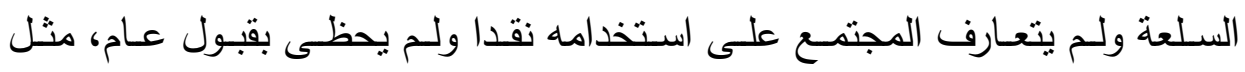
القصدير والرصاص وحبوب القهوة وأوراق الثـاهي، فلا يعتبر نقدا ولا تتطبق عليه شرط الحلول في التبادل، وكذلك لا ينطبق شرط الحلول في تبادل السلّع القيمية مثل

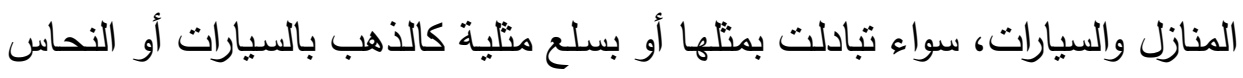
بالخشب. ولكن يستثى من السلع القيمية السلع التي تتمو نموًا طبيعيًا مثل الحيوانات الحيـة، وذلك لتحقيق العدالـة في قيمـة السـلع المنبادلة التي يكون فيها جهالـة لقيم السـلع المتبادلـة حين التبادل إذا كان فيها نسـاء أي تأجيل في تبـادل الحيوان الذي يسمح فيه الفضل فقط، بنـاء على حديث سمرة مرفوعا (نهى رسول الله صلى الله عليه وسلم عن بيع الحيوان بالحيوان نسيئة)(^م).

\section{الترجيح الاقتصادي للعلة الفقهية لربا النساء}

وقد اتفق الفقهاء على حرمسة ربـا النسـاء في الأصـناف الستة الـواردة في

الحديث، ولكن اختلفوا على الأصناف الأخرى لاختلافهم في علة التحريم، فعلة النساء عند المالكية في في المطعومات الطعم والادخار دون اتفاق الصنف، وفي رأي أخر أن العلـة هـي الطعـم فقط، أمسا في الذهب والفضـة هـي الثمنيـة، أمـا الثـافعية، فعلـة النسـاء عندهم الطعم دون اعتبـار الصنف، أمـا الحنفيـة والحنابلـة

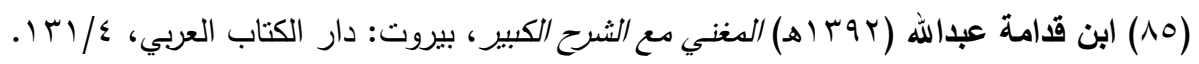


فعلة النساء عندهم اختلاف الصنف في المكيلات والموزونات، والثنية في الذهب والفضة(ז^)، أن النساء يعني فضل الحلول على الأجل، والذي يلعب فيه الأجل أو الزمن تأثثر على قيم المتبادلة، إذ إن للثمن حصـة من الثمن، وحيث إن مقصد تحريم الربا وجود العدل في التبادل ومنع السرف، فكان الكيل والوزن والعدد والذرع هي وسيلة للتقييم وللوصول إلى قيمة السلع المتبادلة فيجب ألا تكون هي العلة في الربـا، إذ قد يصـطلح المجتمـع على بيـع المحقرات بـالوزن أو الكيـل كالرمـل أو الي السماد أو الحديد، وهذه الأصناف لم يقل أحد بأنه يجري فيها الربا على الرغم من توفر العلة، وسبب ذلك أنها لا يمكن أن تستخدم كنقود وتطلب لتبادلها بغيرها ويقبـل بهـا الجميـع لأنـهـ لا تتـوفر فيهـا الصـفات المرغوبــة في النقود، وكـللك المطعومات الواردة في الحديث، فقد جرى فيها الربا ليست لأنها مطعومات فقط، بل لأنها مطعومـات ضـرورية لحياة الإنسـان وتحظى بقبول عام وتصلح كوسيط للتبادل، إذا علة المطعومات هي الثمنية أيضـا وكذللك الذهب والفضـة، وإن الكيل أو الوزن أو الزرع أو العد هي وسيلة لقياس القيمة لهذه الأصناف وبالتالي تحديد ثمن الأشياء بها.

\section{المراجع}

أولاً: المراجع العربية

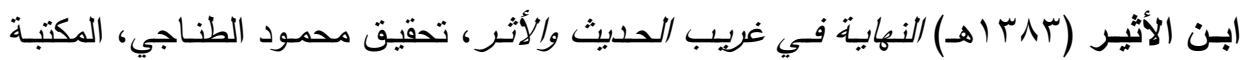

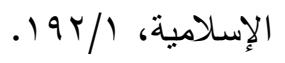

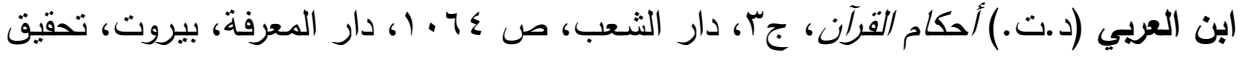

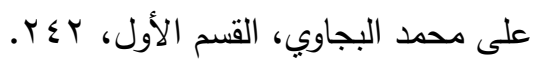

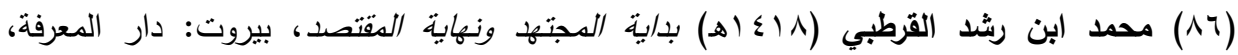

$$
.1 \Lambda r-1 \Lambda \mid / r
$$




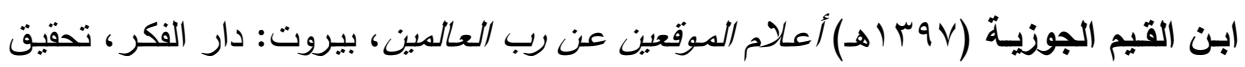

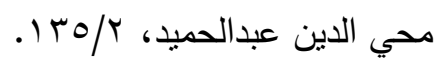

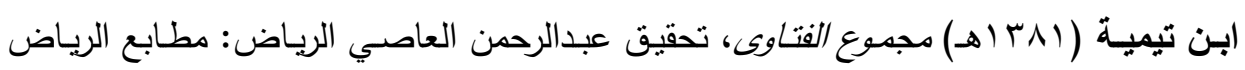
$.170 / 11$

ابـن خلـدون، عبدالرحمن (د.ت.) الدقدة، تحقيـق على عبدالواحد وافي، القـاهرة: دار نهضــة

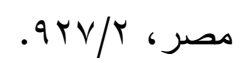

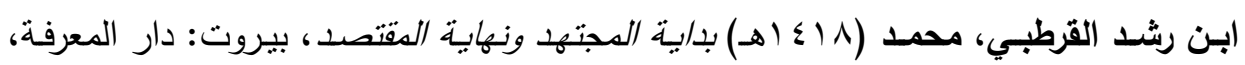
$.111 / \mathrm{r}$

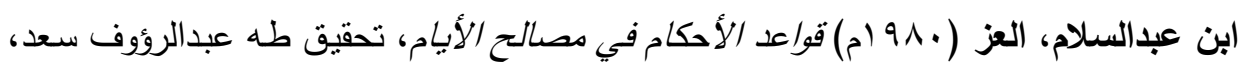

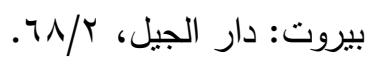

ابـن قدامـة، المقدسي (د.ت.) الدغنسي علسى مختصسر الدقنع، بيـروت: دار الكتاب العربي، .rT/

ابن قدامة، المقدسي (د.ت.) الدغني على مختصر المقنع ، الرياض: مكتبة الرياض الحديثة، $r / \varepsilon$

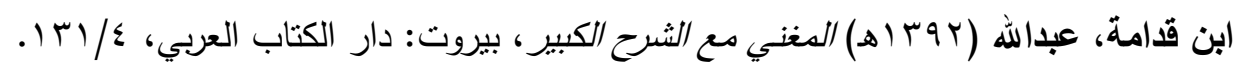

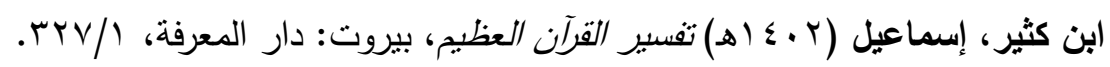

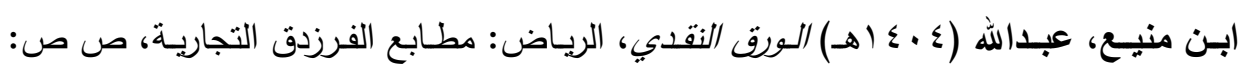
$.110-11 \leq$

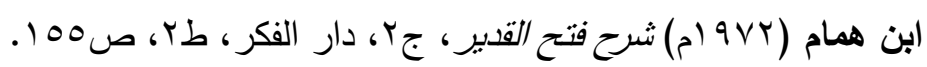

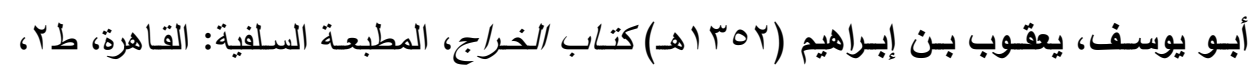
ص ص

إلهي، فضل (7 ـ أهـ) التدابير الواقية من الربا في الإسـاحم، باكستان: إدارة ترجمان الإسـلام، صטזיה

الألوسي، محمود (د.ت.) روح الدعاني في تفسبر القرآن العظبيم والسبع الدثاني، بيروت: دار

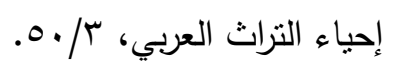

الإمـام مالكك بن أنس (د.ت.) الددونة الكبرى، برواية سحنون بن سعيد التتوخي، بيروت: دار

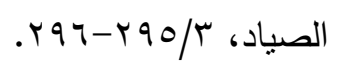




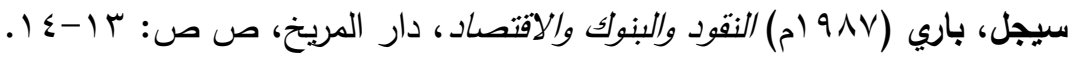
البخـاري، محمد بن إسـماعيل (د.ت.) صحيح البخاري، الرياض: رئاسـة إدارة البحوث العلميـة

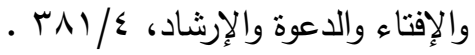
البلاذري، أحمـ (س + ع أهـ) فتوح البلدان، تحقيق: رضـوان محمد رضـوان بيروت: دار الكتب

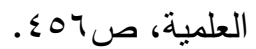

الجزيري، عبدالرحمن (1 ، ع اهـ)كتاب الفقه على المذاهب الأربعة، بيروت: دار الربان للتراث، $r \leqslant 0 / r$

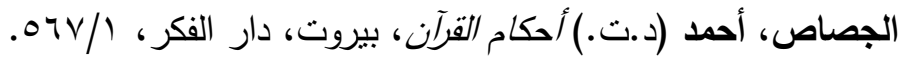

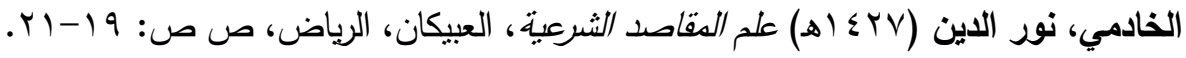
رضا، محمد رشيد (د.ت.) ببر الإسالحم وأصول التشربع، مصر : مطبعة المنار، ص الج. السبكي، على (د.ت.) تكملة المجهوع مسع المجهوع للنـووي، المدينة المنورة: المكتبة السلفية، $.7 \leq / 1$.

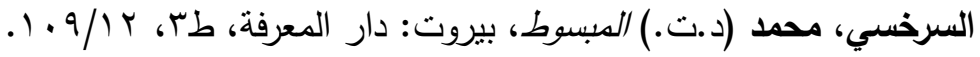

السعدي، عبدالرحمن (د.ت.) تفسبر كلام المنان، الرياض: المؤسسة السعدية، ص / / • ع.

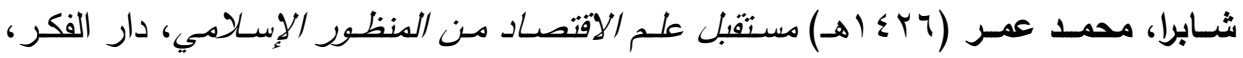
ص ص: v: 1.1-11

الشاطبي، إبراهيم (د.ت.) المواققات في أصول الأحكام، القاهرة: مكتبة محمد علي صبيح، ع/Yع. الشافعي، محمد إدريس (د.ت.) الأم، القاهرة: دار الثعب، الأم، س/ Tr.

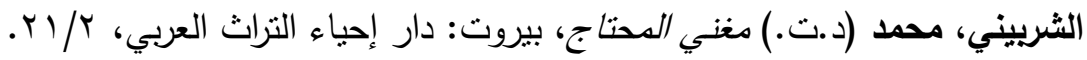
الصـاوي، محمـد صـلاح ( • (ـ اهـ) مشـكلة الاستثمار في البنـوك الإسـالامبة، المنصسورة: دار

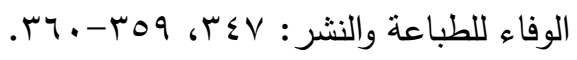
الطبري، محمد بن جرير ( . . ع اهـ) جامع البيان في تفسبر القرآن، بيروت: دار المعرفة، طء، $.7 \mathrm{~V} / \mathrm{r}$

الطبري، محمد بن جرير (د.ت.) جامع البيان في تفسبر القرآن، تحقيق محمود وأحمد شاكر، مصر : دار المعارف، ص إ؟ب.

علي، عبدالمنعم السيد والعيسـ، نـزار (r . . rم) النقود والمصساف والأسواق المالية، عمان:

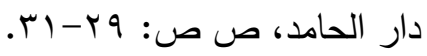




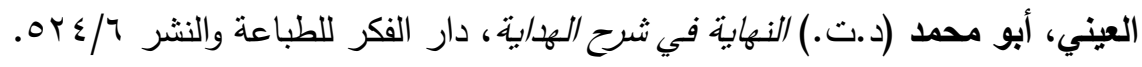

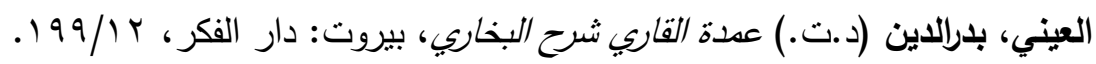

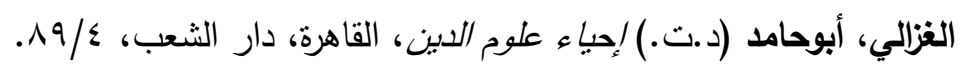

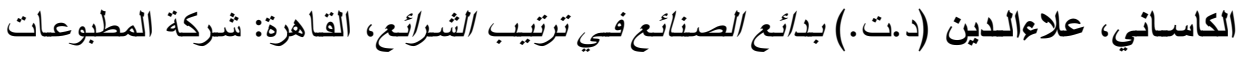

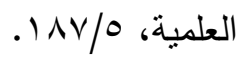

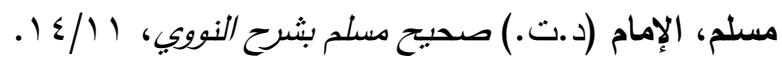

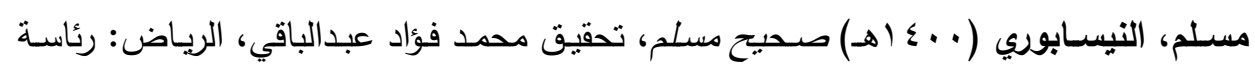

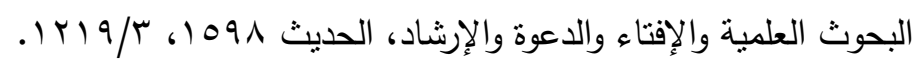

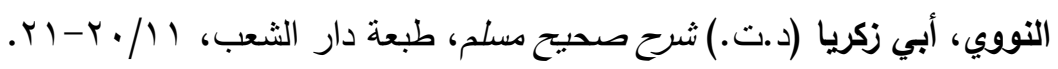

ثانيًا: المراجع الإنجليزية

Baumol, W.J. (1952) The Transaction Demand for Cash: An Inventory Theoretical Approach,Q.J. of Econ. LXVI. pp: 545-56.

Goldfeld, S.M. and Chandler, L.V. (1973) The Economics of Money and Banking, 8ed. Harper \& Row, Publishers, New York, pp: 7-10.

Harris, Laurance (1981) Monetary Theory, McGraw Hill Book Company, pp: 42-44.

Makinen, G.E. (1977) Money, The Price Level \& Interest Rate, Prentice-Hall New Jersy, pp: 152-227, 378-382.

Patinkin, Don (1965) Money, Interest, and Prices, Harper \& Row publishers, New York, p. 150.

Tobin, J. (1956) The Interest Elasticity of Transation Demand for Cash, R. of Econ. And Stat., XXXVIII, pp: 241-47

Vickers, Douglas (1968) The Theory of the Firm: Production, Capital, and Finance, New York: McGrow-Hill, p. 133. 


\title{
The Economic Justification for Riba Alfadel and Riba Alnasia
}

\author{
AbdulRahim A. Al-Saati \\ Islamic Economic Institute \\ King Abdulaziz University, Jeddah, Saudi Arabia \\ a_alsaati@hotmail.com
}

\begin{abstract}
Economic justification for the prohibition of Riba is used to support some of will established Figh views which considered the moneiness (Althamania) in commodities is the reason and the justification of the prohibition of Riba Alfadel and Riba Alnasia which lead by Ibn Alqayem. In this article the well known Hadith of Ebada Ibn Alsamit which specified the Shriah restrictions of exchange the six commodities mentioned in the Hadith. The Hadith is examined and the finding that al the six commodities have the attribute and the characteristics of money commodity, and the Shria restrictions is mint to prevent Zulm or unjust which occur by Riba Alnasia (reward for lending) or Riab AlFadel ( increase in quantity exchange for the same good).
\end{abstract}

